\title{
ARITILMIŞ ATIKSULARIN YENİDEN KULLANIM ALANLARININ DEĞERLENDİRILMESI
}

\author{
Aslıhan KATIP (ORCID: 0000-0002-3210-6702)* \\ Çevre Mühendisliği Bölümü, Mühendislik Fakültesi, Uludağ Üniversitesi, Bursa, Türkiye
}

Geliș / Received: 27.11 .2017

Kabul / Accepted: 13.02.2018

\begin{abstract}
ÖZ
Dünyada kentleşme, nüfus ve endüstrileşmenin artması ve iklim değişikliği nedeni ile su ihtiyacı giderek artmaktadır. Bu çalışmada artan su ihtiyacını karşılamak için evsel, kentsel ve endüstriyel atıksuların arıtılarak yeniden kullanımı konusu araştırılmıştır. Toksik maddeler içeren bazı endüstriyel atıksuların sulama ve su ürünlerinde kullanımı sonucunda, metal birikimleri olduğu, toprağın ve yeraltı suyu kalitesinin bozulduğu ve toprakta tuzluluk problemleri yarattığı görülmüștür. Bu nedenle, evsel, kentsel ve gıda endüstrisi atıksularının temiz su ile karıştırılarak kullanılmasının uygun olduğu ve sulama ve su ürünleri yetiştiriciliği gibi direkt temas gerektiren kullanımlarda metaller, diğer toksik organik/inorganik kirleticiler ve mikrobiyal açıdan iyi su kalitesinde olması gerektiği görülmüștür. Su ürünleri ve sulamada gıda endüstrisi atıksularının kullanımının daha az risk taşıyabileceği ve birbirine yakın konumda bulunan endüstiyel kuruluşların atıksularının yeniden kullanımının endüstriyel simbiyoz yaklaşımı ile değerlendirilmesi gerektiği düşünülmüştür. Gri suların tuvalet temizliğinde kullanımının en uygun yeniden kullanım alanlarından biri olduğu görülmüştür. Ülkemizde arıtılmış atıksuların yeniden kullanımı devlet tarafından teşviklerle yaygınlaștırılmalıdır.
\end{abstract}

Anahtar Kelimeler: Arıtılmış evsel, kentsel ve endüstriyel atıksu, yeniden kullanım, su kirliliği

\section{EVALUATION OF TREATED WASTEWATER REUSE AREAS}

\begin{abstract}
Because of the urbanization, industrialization, population growth and climate change in the world water demand increases rapidly. The reuse of treated wastewater to meet water demand was investigated in this study. It was seen that metal bioaccumulation, the deterioration of soil and water quality and salty problems had been detected with the use of some industrial wastewaters in irrigation and aquaculture. For this reason, the reuse of domestic, urban and food industry wastewaters mixed with clean water was more appropriate. Especially metals, other toxic organic/inorganic pollutants and microbial quality of wastewater should be good water quality level for irrigation and aquaculture. The utilization of food industry wastewater in aquaculture feeding and irrigation had less healty risk. The possibility of reusing each other's wastewater of industiries with the industrial symbiosis approach should be investigated. Grey water usage in toilet could be suitable. The studies of treated wastewater reuse in water management of Turkey should be generalized.
\end{abstract}

Keywords: Treated domestic, urban and industrial wastewater, reuse, water pollution

\section{GİRIŞ}

Su kıtllğg ve kuraklık, dünya çapında yalnızca kurak bölgelerde değil, tatlı su kaynaklarının çok olduğu yerlerde de gittikçe büyüyen bir problemdir [1]. Geçtiğimiz 50 yılda, su miktarı aynı kalmasına rağmen, su çekimi üç katına çıkmıştır [2]. Birçok bölgede yeraltı suyu çekimleri geri besleme miktarının ve sürdürülebilir kullanım miktarının üzerindedir. Su kaynakları küresel değişimlerden önemli bir şekilde etkilenmektedir. Dünya

"Corresponding author / Sorumlu yazar. Tel.: +90 224 2940918; e-mail / e-posta: aballi@uludag.edu.tr 
üzerinde insan aktivitelerinden etkilenmemiş olan çok az yüzey ve yeraltı suyu sisteminin kaldığı bilinmektedir [3].

2012 yılında 7,1 milyar olan Dünya nüfusunun 2030 yılında 8,3 milyar olması beklenmektedir. Nüfus ve kentleşmenin giderek artacağı ve nüfusun yaklaşık \%60'ının kentlerde yaşayacağı öngörülmektedir [3]. Bu durum su kaynaklarının miktarı ve kalitesi üzerindeki baskıları daha da artıracaktır.

Afrika' nın büyük bir bölümü ile Hindistan'da, Orta Doğu, Asya ve Amerika kıtasının bir bölümünde su kıtlığı yaşanmaktadır. Aynı zamanda Türkiye ve Avrupa ülkelerinin bir kısmında fiziksel su kıtllğı tehlikesinin yaklaştığı görülmektedir [4]. Birçok ülke suyun yeniden kullanımı uygulamaları için ulusal ya da bölgesel talimatlar veya kılavuz ilkeler uygulamaktadır. Çevrenin korunmasına yönelik yasal düzenlemeler ve işletmelerde su ihtiyacının giderek artmasından dolayı teknolojilerin iyileştirilmesi ve işletme içi madde döngüleri öne çıkmakta, atık su oluşumunun en aza indirilmesi, değerli maddelerin kazanılması ve suların tekrar kullanımı giderek önem kazanmaktadır [5]. Ülkemizde, su temini ve atıksu arıtma ihtiyacının belirlenmesi, atıksuyun yeniden kullanılmasının su teminine yararlarının vurgulanması, geri kazanılmış atıksuyun pazarlanması, mühendislik açısından ekonomik olarak alternatiflerin değerlendirilmesi ve maliyet analizi yeterince yapılmamaktadır. Ayrıca, atıksuyun geri kazanılması ve yeniden kullanılmasına yönelik tesislerin planlanmasında takip edilecek adımlar konusunda henüz yeterli seviyeye gelinmemiş olup, eksiklikler söz konusudur [6].

$\mathrm{Bu}$ çalışmada evsel, kentsel ve endüstriyel atıksuların arıtılarak yeniden kullanım alanları, avantaj ve dezavantajları ve göz önüne alınması gereken parametreler literatürden araştıılarak derlenmiştir. Ülkemizde ve dünyada kentleşmenin, nüfusun ve endüstrileşmenin artması ve iklim değişikliği sebebiyle hemen hemen tüm sektörlerde su ihtiyacı her geçen yıl artmaktadır. Bu çalışma ülkemizde su ihtiyacını karşılayabilmek, çevresel kriterleri sağlayabilmek ve iklim değişikliği ile uyum çalışmaları için arıtılmış atıksuların yeniden kullanımı konusunda yapılması gerekenlerin belirlenebilmesi açısından önemlidir.

\section{DÜNYA'DA ARITILMIŞ ATIKSULARIN YENIDEN KULLANIMI}

Nüfusun, tarımsal faaliyetlerin ve endüstrileşmenin artmasıyla yeraltı ve yüzey suları yetersiz kalmaktadır ve birçok ülke su ihtiyacını karşılayabilmek için atıksuların yeniden kullanımına yönelmektedir [7].

Dünya Sağlık Örgütü (WHO) suyun yeniden kullanımını şu sınıflara ayırmaktadır: "Direkt yeniden kullanım" arıtılmış atıksuyun sulama, endüstriyel kullanım, akifer dolumu, içme suyu gibi belirli bir amaç için planlı ve düşünülmüş bir şekilde kullanımıdır; "Dolaylı kullanım" ise suyun, evsel ya da endüstriyel amaçlar için bir defa ya da daha fazla yeniden kullanılması ve yüzey ya da yeraltı suyuna deşarj edilmesi ve seyreltilmiş formda yeniden kullanılması; "Geri dönüşüm" ise su tasarrufu ya da kirlilik kontrolü amacıyla endüstriyel tesisler dahilinde suyun yeniden kullanılmasıdır [8].

Suyun yeniden kullanımı ayrıca "İçme suyu amaçlı" ve "İçme suyu amaçlı olmayan" yeniden kullanımı olmak üzere 2 sınıfa ayrılmaktadır. İlki, doğrudan ya da dolaylı olarak, akifer ve yüzey kaynağının doldurulması, ikincisi ise kentsel, tarımsal, endüstriyel, çevresel, rekreasyonel ve su ürünleri yetiştiriciliği gibi amaçlarla yeniden kullanımıdır [8].

Dünya'da atıksuların yeniden kullanımında birçok farklı geri kazanım yöntemleri kullanılmaktadır. Bixio ve arkadaşları 2005 yılında yaptıkları bir çalışmada atıksu kullanım çeşitlerini 4 ayrı kategoride toplamışlardır: 1) tarımsal kullanım, 2) kentsel kullanım ve akifer sularının yenilenmesi, 3) endüstriyel kullanım, 4) karışık kullanımlar. Arıtılmış atıksuların dünya çapında tarımsal, endüstriyel ve evsel amaçlı kullanım oranları sırasıyla $\% 70, \% 20$ ve $\% 10$ 'dur. Ancak bu oranlar dünyanın her bölgesinde farklılık göstermektedir. Atık suyun tarım gibi bazı amaçlarla yeniden kullanımı, entegre su yönetiminin vazgeçilmez bir parçası olduğu ve su kıtllğını azaltacağı düşünülmektedir. Bu kullanım, algılamada bir değişikliğin yanı sıra basit, düşük maliyetli ve etkili teknolojilerin bulunmasını gerektirmektedir [9].

Bu uygulama Fas, Tunus, Mısır, Sudan, Namibya, Hindistan ve Çin gibi gelişmekte olan ülkelerde kanalizasyon suları sebze türleri ve diğer kısa vadeli tarımsal ürünlerin sulanmasında ve balık kültürünün yetiştirilmesinde kullanılmaktadır [10]. Son yıllarda, arıtılmış atıksuların yeniden kullanımı, Avrupa, Amerika Birleşik Devletleri ve Çin'de yılda \% 10 ile \%29 arasında, Avustralya'da ise \% 41 oranlarında olup, günlük kullanılan su hacmi Kaliforniya ve Florida eyaletlerinde ve Meksika ve Çin gibi ülkelerde 1,5-1,7 milyon $\mathrm{m}^{3} /$ gün gibi yüksek miktarlara ulaşmıştır [11]. Kullanım amaçlarına göre baktığımızda, arıtılmış atıksuların tarımda kullanımının en çok Çin'de olduğu (200000 ha) görülmüştür. Amerika Birleşik Devletleri'de 20000 ha, Almanya ve Fransa'da 5000 ile 10000 ha arasında bulunmuştur. Akdeniz kıyısında bir Avrupa Ülkesi olan İtalya'da ise tarımsal kullanım 20000 ha civarında olup diğer Avrupa Ülkelerinden yüksektir. İsrail ve Güney Amerika Ülkelerinde ise sulama yapılan alan büyüklüğ̈̈nün Çin'den sonra yüksek seviyelerde (50000 ile 150000 ha arasında) olduğu görülmüştür [12]. 
Arap ülkelerinde arıtılmış atıksuların yeniden kullanım miktarı yılda 1,2 milyar $\mathrm{m}^{3}$ olarak belirlenmiştir. Suriye, Suudi Arabistan ve Mısır arıtılmış atıksularını en çok kullanan ülkelerdir ancak bölgedeki atıksuların yeniden kullanımın gelişigüzel yapılması ve arıtılmamış atıksuların sulamada kullanılması sonucunda önemli sağlık riskleri görülmüştür [13]. Arıtılmış atıksuların endüstriyel amaçlı kullanımı Avrupa ülkelerinde oldukça yaygındır. Lüksenburg, Danimarka ve İsveç \% 80'in üzerinde endüstriyel atıksularını yeniden kullanmaktadırlar. Belçika ve Hollanda endüstriyel atıksularını \%20’nin altında yeniden kullanmaktadırlar [14]. Arıtılmış atıksuların dünyanın farklı bölgelerinde kullanım durumu Şekil 1'de gösterilmiştir.

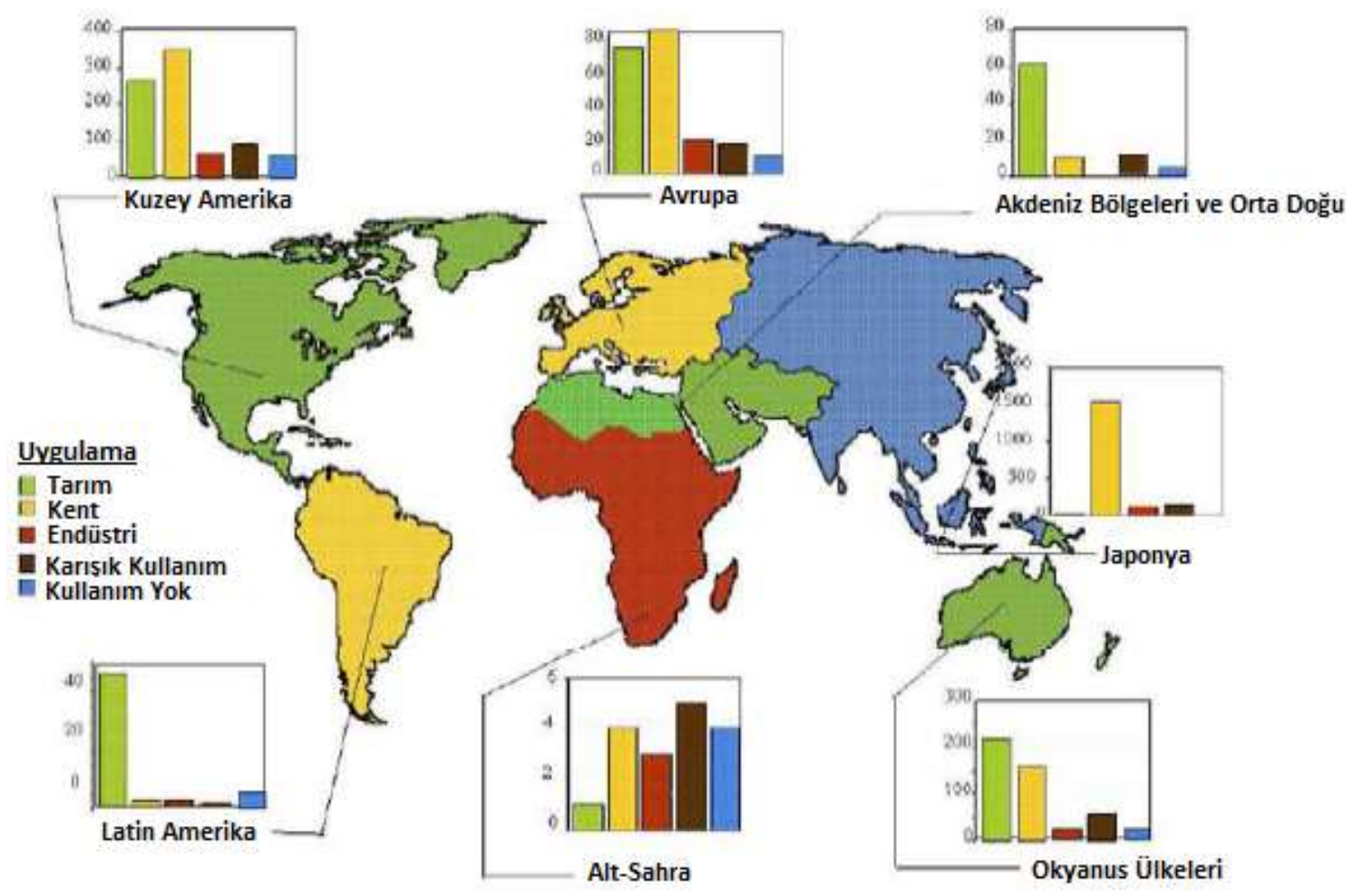

Şekil 1. Arıtılmış atıksuların dünyanın farklı bölgelerinde kullanım durumu [11]

\subsection{Arıtılmış Atıksuların Yeniden Kullanımı ile İlgili Parametreler}

Arıtılmış atıksuların farklı amaçlarla yeniden kullanımı ile ilgili parametreler kullanım amacına ve ülkelere göre değişiklik göstermektedir. Ülkemizde, “Atıksu Arıtma Tesisleri Teknik Usuller Tebliği’nde” atıksuların geri kazanımı ve yeniden kullanımına ilişkin düzenlemeler yer almaktadır [15]. Tebliğ'de "Atıksu geri kazanımı için uygulanan arıtma teknolojileri ve giderdikleri kirleticiler" tablosunda, askıda katı maddeler (AKM), kolloidal maddeler, partiküler ve çözünmüş organik maddeler, azot, fosfor, eser maddeler, toplam çözünmüş maddeler, bakteri, protozoa ve virüsler giderilmesi gereken parametreler olarak belirtilmiş ve arıtma yöntemleri verilmiştir. Aynı tebliğde “Atıksu geri kazanım maksadı ve uygulabilecek arıtma sistemleri” tablosunda, yeşil alan, golf sahaları ve tarımsal sulama, sulakalan beslemesi, dolaylı kullanım suyu (yeraltı ve yüzey sulara deşarj), endüstriyel soğutma ve proses suyu amaçlı olarak biyolojik arıtma, filtrasyon, ileri arıtma ve dezenfeksiyon işlemlerinden sonra kullanılabileceği belirtilmiştir. Bu Tebliğ'de sulama suyu amaçlı kullanım için ölçülen parametrelere ve arıtım proseslerine geniş yer verilmiştir. BO $\dot{I}_{5}, \mathrm{pH}$, bulanıklık, fekal koliform, virüs, protozoa ve helmint analizi ve bakiye klor, tuzluluk, SAR (sodyum adsorpsiyon oranı; $\mathrm{Na}^{+}, \mathrm{Ca}^{+2}, \mathrm{Mg}^{+2}$ ), $\mathrm{B}$ ve diğer iz elementler ve ağır metal parametrelerinin, sulama suyu amaçlı kullanım için standart değerleri sağlaması gerekmektedir [15]. Ayrıca, "Sulama Sularının Kalitesi ve Kullanılmış Suların Yeniden Kullanılması Hakkında Yönetmelik" kapsamında bu kriterlere ek olarak $\mathrm{NO}_{3}-\mathrm{N}$, toplam pestisit, bikarbonat $\left(\mathrm{HCO}_{3}{ }^{-}\right)$ve E. coli sayısı da ilave edilmiştir [16].

Uluslararası mevzuat kapsamında değerlendirildiğinde, "2000/60/EC sayılı Avrupa Birliği Su Çerçeve Direktifi” EK-VI suyun yeniden kullanımı ve planlaması için önemli düzenlemeler içermektedir. Endüstride verimli su teknolojileri ve su tasarrufu sağlayarak sulama tekniklerinin teşvik edilmesi tamamlayıcı önlem olarak 
yer almıştır. Ancak bu direktifte herhangi bir rehber bulunmamaktadır. Avrupa Birliğine üye olan Fransa, Yunanistan, Güney Kıbrıs, İtalya, Portekiz ve İspanya gibi birçok ülke atıksuların yeniden kullanımına ilişkin kendi yasal düzenlemelerini ve rehberlerini oluşturmuşlardır [17, 18]. Bu ülkelerin yasal mevzuatlarında, geri kazanılan suların kullanım alanları, ölçülen parametreleri ve maksimum sınır değerleri, izleme protokolleri ve halk sağlığı için ek koruyucu önlemleri kapsamaktadır. Su kıtlığı yaşayan Avustralya'da ve Ülkemize benzer Akdeniz ülkeleri olan Yunanistan ve İspanya'da geçerli olan mikrobiyolojik ve fizikokimyasal parametreler Tablo 1'de gösterilmiştir.

Tablo 1. Yunanistan, İspanya, Avustralya ve Türkiye'de atıksuların yeniden kullanım kriterleri [15, 19, 20, 21]

\begin{tabular}{|c|c|c|c|c|c|}
\hline \multirow[b]{2}{*}{ Atıksu yeniden kullanımı ${ }^{a}$} & \multicolumn{5}{|c|}{ Kalite parametresi } \\
\hline & \multicolumn{2}{|c|}{ Mikrobiyolojik } & \multicolumn{3}{|c|}{ Fizikokimyasal } \\
\hline & $\begin{array}{c}\text { Nematod } \\
\text { yumurtalar1 }\end{array}$ & $\begin{array}{c}\text { Escherichia } \\
\text { Coli }\end{array}$ & $\mathrm{AKM}^{\mathrm{d}}$ & $\begin{array}{c}\text { Bulanıklı } \\
\mathrm{k}\end{array}$ & $\begin{array}{c}\text { Diğer } \\
\text { parametreler }\end{array}$ \\
\hline $\begin{array}{l}\text { Kentsel kullanım } \\
\text { a) Yerleşke kullanımları: Şahsi } \\
\text { bahçe sulama, tuvalet sifonu, ev } \\
\text { klima sistemleri, araba yıkama }\end{array}$ & $\begin{array}{c}<1 \\
\underset{2}{\text { yumurta/10L }} \mathrm{L}^{1} \\
\mathrm{~L}_{\mathrm{L}^{3}}^{\text {yumurta/ }}\end{array}$ & $\begin{array}{l}0 \mathrm{cfu} / 100 \mathrm{~mL}^{1} \\
<10 \\
\mathrm{cfu} / 100 \mathrm{~mL}^{3}\end{array}$ & $<10 \mathrm{mg} / \mathrm{L}^{1,2,3}$ & $\begin{array}{c}<2 \\
\text { NTU }^{1,2,3}\end{array}$ & - \\
\hline $\begin{array}{l}\text { b) Kentsel kullanımlar ve } \\
\text { tesisler: Serbest girişli alanların } \\
\text { (parklar, golf vb. spor sahaları) } \\
\text { sulanması, sokak temizliği, } \\
\text { yangın söndürme, fiskiyeler ve } \\
\text { diğer rekreasyonel amaçlar }\end{array}$ & 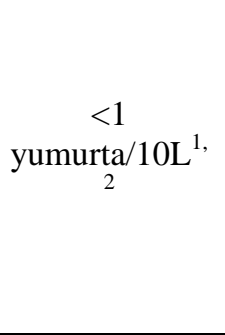 & $\begin{array}{c}<10 \mathrm{cfu}^{1} \\
/ 100 \mathrm{ml} \\
<200 \mathrm{cfu}^{2} \\
/ 100 \mathrm{~mL} \\
<1000 \mathrm{cfu}^{3} \\
/ 100 \mathrm{~mL} \\
0 \mathrm{cfu}^{4} / 100 \mathrm{~mL}\end{array}$ & $\begin{array}{c}<20 \mathrm{mg} / \mathrm{L}^{1} \\
<20 \mathrm{mg} \\
\mathrm{AKM}^{2} / \mathrm{L} \\
<30 \mathrm{AKM}^{3} \\
\mathrm{mg} / \mathrm{L}\end{array}$ & $\begin{array}{c}<5 \mathrm{NTU}^{1} \\
<10 \\
\mathrm{NTU}^{2} \\
<2 \mathrm{NTU}^{4}\end{array}$ & $\begin{array}{c}\mathrm{BOİ}^{3,4} \\
<20 \mathrm{mg} / \mathrm{L}\end{array}$ \\
\hline $\begin{array}{l}\text { Su ürünleri yetiștiriciliğgic,f } \\
\text { a) Su ürünleri yetiştiriciliği } \\
\text { (bitkisel ve hayvansal } \\
\text { biyokütlenin üretimi) }\end{array}$ & $\begin{array}{c}<1 \\
\text { yumurta/10 } \\
, 2\end{array}$ & $\begin{array}{l}<1000 \mathrm{CFU} \\
/ 100 \mathrm{~mL}^{1,2}\end{array}$ & $35 \mathrm{mg} / \mathrm{L}^{1,2}$ & $\begin{array}{l}\text { Belirlen } \\
\text { miş bir } \\
\text { sinır } \\
\text { değer } \\
\text { yok }\end{array}$ & $\begin{array}{c}\text { Tehlikeli } \\
\text { maddeler ve } \\
\text { diğer } \\
\text { patojenler } \\
\text { olmamalı }^{2}\end{array}$ \\
\hline Endüstriyel kullanım & $\begin{array}{l}\text { Soğutma suyu } \\
\text { ve gida } \\
\text { endüstrisi için } \\
<1 \\
\text { yumurta/10L }\end{array}$ & $\begin{array}{c}<10,000 \\
, 2 \text { cfu/ } 100 \mathrm{~mL} \\
\text { (soğutma } \\
\text { suyu) } \\
<1 \text { cfu/100mL } \\
\text { (g1da) }\end{array}$ & $\begin{array}{c}<35 \mathrm{mg} / \mathrm{L}^{1,2} \\
\text { (soğutma ve } \\
\text { gida } \\
\text { endüstrisi) } \\
<5 \mathrm{mg} / \mathrm{L}^{1,2} \\
\text { (soğutma ve } \\
\text { buhar } \\
\text { kondensatörler } \\
\text { i) }\end{array}$ & $\begin{array}{l}\text { Belirlen } \\
\text { miş bir } \\
\text { sınır } \\
\text { değer } \\
\text { yok }\end{array}$ & $\begin{array}{c}\text { Legionella } \text { pheumophila }_{1} \\
\text { Diğer }^{1,2} \\
\text { kirleticiler }^{\text {sağllk }} \\
\text { otoritelerine }^{\text {uymalı }}\end{array}$ \\
\hline $\begin{array}{l}\text { Cevresel kullanım ve } \\
\text { rekreasyon } \\
\text { a) Kamuya açık havuzlar, } \\
\text { rekreasyonel amaçlı su } \\
\text { kaynakları ve akarsular } \\
\text { (yıkanma amacı hariç) }\end{array}$ & $<1^{1}$ yumurta/L & $\begin{array}{c}<200^{1} \\
\mathrm{cfu} / 100 \mathrm{~mL}\end{array}$ & $<35^{1} \mathrm{mg} / \mathrm{L}$ & $\begin{array}{c}\text { Belirlen } \\
\text { miş bir } \\
\text { sinır } \\
\text { değer } \\
\text { yok }\end{array}$ & $\begin{array}{c}\mathrm{NO}_{3}{ }^{1}<100 \\
\mathrm{mg} / \mathrm{L}\end{array}$ \\
\hline $\begin{array}{c}\text { b) Kamuya açık olmayan } \\
\text { havuzlar, su kaynakları ve süs } \\
\text { akarsuları }\end{array}$ & $\begin{array}{l}\text { Belirlenmiş } \\
\text { bir sınır değer } \\
\text { yok }\end{array}$ & $\begin{array}{c}<100^{1} \mathrm{cfu} / 100 \\
\mathrm{~mL} \\
10000^{2} \mathrm{cfu} / 100 \\
\mathrm{~mL}\end{array}$ & $<35^{12} \mathrm{mg} / \mathrm{L}$ & $\begin{array}{c}\text { Belirlen } \\
\text { miş bir } \\
\text { sinır } \\
\text { değer } \\
\text { yok }\end{array}$ & $\begin{array}{c}\mathrm{NO}_{3}{ }^{1}<100 \\
\mathrm{mg} / \mathrm{L} \\
\text { Diğer } \\
\text { kirleticiler } \\
\text { çevre } \\
\text { kalitesi } \\
\text { standartların } \\
\text { a uymalıdır }\end{array}$ \\
\hline Yeraltı su dolumu & $<1^{1}$ yumurta/L & $<1000^{1,2}$ & $<35^{1,2} \mathrm{mg} / \mathrm{L}$ & Belirlen & Toplam \\
\hline
\end{tabular}




\begin{tabular}{|c|c|c|c|c|c|}
\hline $\begin{array}{l}\text { a) Yeraltı Su Dolumu }{ }^{c, e} \text {, yüzey } \\
\text { yayılımı (toprak aracıllı̆gyla) }\end{array}$ & $\begin{array}{l}\text { Sinır değer } \\
\text { yok }^{2}\end{array}$ & $\mathrm{cfu} / 100 \mathrm{~mL}$ & & $\begin{array}{l}\text { miş bir } \\
\text { sinır } \\
\text { değer } \\
\text { yok }\end{array}$ & $\begin{array}{c}\text { Azot } \\
<50^{1} \mathrm{mg} / \mathrm{L} \\
\text { Toplam } \\
\text { Azot } \\
<10^{2} \mathrm{mg} / \mathrm{L}\end{array}$ \\
\hline $\begin{array}{l}\text { b) Yeraltı Su Dolumu: } \\
\text { doğrudan pürkürtme }\end{array}$ & $\begin{array}{c}<1^{1,2} \\
\text { yumurta/10L }\end{array}$ & $\begin{array}{c}0^{1,2} \\
\mathrm{cfu} / 100 \mathrm{~mL}\end{array}$ & $<10^{1,2} \mathrm{mg} / \mathrm{L}$ & $\begin{array}{l}<2^{1,2} \\
\text { NTU }\end{array}$ & $\begin{array}{c}\text { Toplam } \\
\text { Azot } \\
<15^{1} \mathrm{mg} / \mathrm{L} \\
\text { Toplam } \\
\text { Azot } \\
<10^{2} \mathrm{mg} / \mathrm{L}\end{array}$ \\
\hline
\end{tabular}

${ }^{\text {a }}$ İkincil ya da eşdeğeri minimum atıksu arıtım seviyesi.

${ }^{\mathbf{b}}$ Şu türleri de içeren bağırsak solucanları: Strongyloides, Trichostrongylus, Toxocara, Enterobius and Capillaria.

${ }^{\mathbf{c}}$ Koku kontrolü gereklidir

'AKM: Askıda katı madde

e 5 metrede gerekli minimum yeraltı suyu derinliği

${ }^{\mathbf{f}}$ İnsanlar tarafından tüketilen bitkiler hariç (Yunan yasaları tarafından yasaklanmıştır) arıtılıış atıksular tarımsal amaçlar için yeniden kullanılabilir.

\section{${ }^{1}$, Yunanistan, ${ }^{2}$ İspanya, ${ }^{3}$ Avustralya, ${ }^{4}$ Türkiye kriterleri}

Yunanistan ve İspanya'da tüm kullanım alanları için arıtılmış atıksuların fiziko-kimyasal ve mikrobiyolojik parametleri ve sınır değerleri belirlenmiştir ve su ürünleri ve tarımsal kullanımı insanların tüketimi dışında olması gerekmektedir. Yeraltı su dolumu amacıyla kullanımı için toplam azot değerleri dışında bu iki ülkenin snır değerleri birbirine yakındır ve genellikle Yunanistan'ın sınır değerleri daha düşüktür. Avustralya'da ise kullanım amaçlarının tamamında ortak kalite parametreleri bulunmamaktadır. Bulunan sınır değerler Yunanistan ve İspanya'dan daha yüksektir. Ülkemizde ise atıksuların sulama dışında yeniden kullanımına ait kalite kriterleri bulunmamaktadır. Ülkemizdeki kentsel alanların sulama kriterlerinin Yunanistan ve İspanya sınır değerlerine yakın ve daha düşük seviyede olduğu görülmüştür. Amerika Birleşik Devletleri (ABD)'de suyun yeniden kullanımı Arizona, Kaliforniya, Florida, ve Washington gibi eyaletler düzeyinde yapılmış yönetmeliklerle düzenlenmiştir. Dünya Sağlık Örgütü (WHO) tarım ve su ürünleri için kullanımını, Amerika Birleşik Devletleri Çevre Koruma Ajansı (USEPA) akifer besleme ve golf sahalarıın sulanması konusunda kullanım önerilerini, bu kullanımlar için gerekli olan arıtma türlerini, mikrobiyolojik, fiziksel ve kimyasal parametreler ve izleme sıklığını, potansiyel etkilenebilecek çevrenin izlenmesini ve damla sulama, içme suyu kaynaklarına tampon mesafe ve sulama boyunca halk ulaşımının engellenmesi gibi yerinde önleyici tedbirler yapılması gerekenleri ele almışlardır. Bu dökümanlar, sınırlı miktarda endüstriyel atıksu girişinin olduğu arıtma tesislerinden ve evsel atıksular için uygulanmaktadır ve yasal ve zorunlu değildir. Bölgesel düzeyde değişebilmekte ve hedefe ulaşmayı sağlamaktadır. 2015 yılında Uluslararası Standartlar Teşkilatı'nın (ISO) hazırladığı ISO 16075 standartta arıtılmış atıksu ile sulama projelerinin dizaynı, sağlık riskleri ve azaltılması için stratejiler, sulanabilecek ürün deseni, atıksu sulaması yapılan yer ile konut alanları arasındaki mesafe gibi konuları açıklamıştır [22].

Arıtılmış atıksuların farklı ülkelerde yeniden kullanımı avantajlarının yanı sıra parametrelerin belirlenmesi, izlenmesi, standartların oluşturulması, su yönetimi ve maliyetlerin karşılanması gibi dezavantajlara sahiptir ve bu durum uygulama aşamasında problemlere neden olmaktadır. $\mathrm{Bu}$ sorunlar, çözümü ile ilgili sorumlu kişi/kuruluşlar ve yapılması gerekenler Tablo 2'de özetlenmiştir.

\subsection{Arıtılmış Atıksuların Tarımsal Sulamada Kullanımı}

Tarım sektörü, suyun en fazla kullanıldığı sektörlerin başında gelmektedir. Amerika Birleşik Devletleri Jeoloji Kurumu'na göre sulama için kullanılan su, termik santraller hariç dünyanın tatlı su kaynakları kullanımının \%65'ini oluşturmaktadır. ABD'de tarımsal amaçlarla kullanılan yaklaşık 1,3 milyar dönümlük arazi bulunmaktadır [24]. Bu yüksek oranlarda kullanım dünyanın su sıkıntısı olan bölgeleri başta olmak üzere birçok bölgesini yeni su kaynakları aramaya itmiştir, atıksular bu kaynaklardan biridir.

Gerekli arıtım işlemleri yapıldığı ve teknik usuller uygulandığı sürece, arıtılmış atıksuların sulamada yeniden kullanılmasının bir takım faydaları aşağıda sıralanmışıı [25]. 


\section{A. KATIP}

Tablo 2. Evsel ve endüstriyel atıksuların yeniden kullanımı uygulamalarında karşılaşılan başlıca sorunlar [23]

\begin{tabular}{|c|c|c|}
\hline Problem & $\begin{array}{c}\text { Yetkili } \\
\text { Kurum/Kişiler }\end{array}$ & Yorum \\
\hline Tehlike/risk ile alakalı konular & Sağlık otoriteleri & $\begin{array}{l}\text {-Standartlar ile ilgili gereken } \\
\text { yapılmalı } \\
\text {-Daha ayrıntılı yönergelere ihtiyaç } \\
\text { vardır. Sağlıkla ilgili problemler } \\
\text { yeniden kullanım uygulamalarını } \\
\text { sınırlandırır. }\end{array}$ \\
\hline Kalite değerlendirmesi & $\begin{array}{l}\text {-Nihai kullanıcılar } \\
\text {-Arıtma tesisleri } \\
\text { yönetimi } \\
\text {-Su ve sağlık } \\
\text { otoriteleri }\end{array}$ & $\begin{array}{l}\text {-Anlık numunelerin ölçümleri } \\
\text { genellikle gerçeği yansitamaz. } \\
\text {-Analitik çalışma maliyetlidir. } \\
\text {-Mikrobiyal indikatörler tam } \\
\text { anlamıyla temsili değildir. } \\
\text {-Tehlikeli kimyasallar tam olarak } \\
\text { belirlenmiş değildir. }\end{array}$ \\
\hline Epidemiyolojik çalışmaların uygulanması & $\begin{array}{l}\text {-Araştırma } \\
\text { kurumları } \\
\text {-Sağlık otoriteleri }\end{array}$ & $\begin{array}{l}\text {-Atıksuların yeniden kullanımında } \\
\text { epidemiyolojik çalışmaları planlamak } \\
\text { zordur. } \\
\text { - Az miktarda epidemiyolojik veriye } \\
\text { ulaşılabilmektedir. }\end{array}$ \\
\hline Arıtma ve yeniden kullanımın toplumsal yönleri & $\begin{array}{l}\text {-Su ve sağlık } \\
\text { otoriteleri } \\
\text {-Nihai kullanıcılar } \\
\text {-Etkilenen halk } \\
\text {-Çevre dostu } \\
\text { örgütler }\end{array}$ & $\begin{array}{l}\text {-Yeniden kullanım kaynaklarının } \\
\text { toplumsal kabul edilebilirliği çok } \\
\text { önemlidir. } \\
\text { - Toplumsal gereçlerin geliştirilmesi } \\
\text { gerekir. } \\
\text { - Toplumsal politikalar yürürlüğe } \\
\text { konmak zorundadır. }\end{array}$ \\
\hline Standartların zorunlu seviyelerinin belirlenmesi & Sağlık otoriteleri & $\begin{array}{l}\text {-Yeniden kullanım uygulamalarında } \\
\text { standartların seviyeleri ile sağlık } \\
\text { açısından risk seviyeleri arasındaki } \\
\text { ilişki belirgin değildir. }\end{array}$ \\
\hline Planlama yöntemleri & Su otoriteleri & $\begin{array}{l}\text {-Havza içerisindeki tüm su } \\
\begin{array}{l}\text { kaynaklarının bütüncül } \\
\text { gereklidir. }\end{array}\end{array}$ \\
\hline Aritmalar & $\begin{array}{l}\text {-Su otoriteleri } \\
\text {-Tesislerin işletimi } \\
\text { ve yönetimi }\end{array}$ & $\begin{array}{l}\text {-Arıtmanın güvenilirliği üzerine } \\
\text { odaklanılmalıdır. İkincil ve üçüncül } \\
\text { arıtma arasında net bir bağlantı } \\
\text { kurulmalıdır. } \\
\text {-Mevcut göstergelerle arıtma sistemin } \\
\text { performansını belirlemek kolay } \\
\text { değildir. }\end{array}$ \\
\hline Maliyet & $\begin{array}{l}\text {-Su otoriteleri } \\
\text {-Son kullanıc1lar }\end{array}$ & $\begin{array}{l}\text {-Para ve enerji açısından arıtım ve } \\
\text { yeniden kullanım masraflı olabilir. } \\
\text { Arıtma ve kontrol masraflarını kimin } \\
\text { karşılaması gerektiği net değildir. } \\
\text {-Daha az enerji tüketen arıtım } \\
\text { yöntemleri uygulanmalıdır. }\end{array}$ \\
\hline $\begin{array}{l}\text { Yetki problemleri/otoriteler arasında } \\
\text { anlaşmazlıklar }\end{array}$ & $\begin{array}{l}\text { Otoriteler/mevzuat } \\
\text { oluşturanlar }\end{array}$ & $\begin{array}{l}\text { Otoriteler arasındaki ölçüt } \\
\text { farklılıkları: su/sağlık/tarım ya da } \\
\text { ulusal/bölgesel/yerel }\end{array}$ \\
\hline
\end{tabular}


- Su tasarrufu sağlamaktadır,

- Kurak geçen mevsimlerde alternatif su kaynağı oluşturur,

- Yeraltı suyuna karışmadan önce atıksuya ek bir arıtma sağlar,

- Kentsel atıksuların çevreye zarar vermeyecek bir şekilde ve ekonomik olarak uzaklaştırılmasını mümkün kılar,

- Atıksuyun kendi kaynağında tekrar kullanılması alıcı ortama yapılan deşarjları azaltır. Böylece, akarsu ve kanalların ve diğer yüzeysel su kaynaklarının kirliliğini azaltır,

- Yapay gübre ihtiyacını azaltarak besin maddesinden tasarruf sağlar,

- Bitki verimini arttırrr,

Evsel atıksuların arıtılarak tarımsal kullanım için sulama amaçlı olarak araziye uygulandığı en eski kanalizasyon sistemi on altı ve on yedinci yüzyıllarda Almanya'nın Bunzlau kentinde ve Edinburgh, İskoçya'da işletilmiştir [26]. Latin Amerika'da $400 \mathrm{~m}^{3} / \mathrm{s}^{\prime}$ lik ham atıksu yüzeysel sulara deşarj edilmekte ve neredeyse 500000 hektarlık tarım arazisi büyük bir kısmı arıtılmamış olan atıksuyla sulanmaktadır (Meksika-350000 ha, Chile-16000 ha, Peru and Argentina-5500-3700 ha). Meksika'da atıksuyla sulama 1926'da farklı ürünlerin sulanmasıyla başlamıştır ve bundan 80 yıl sonra atıksular 40 farklı yeniden kullanım alanına sahip olmuştur ki bunun yalnızca \%11'i toplam 350000 hektarlık tarımsal alanın sulanması için arıtılmaktadır [11].

Uganda'da atıksuyun yeniden kullanımı çok yaygın değildir, ancak ülkenin bazı bölgelerinde resmi olmayan sulamalar gerçekleştirilmektedir. Örneğin Murchison Bay'da Kampala şehrinin en yüksek atıksu akışını temin eden çiftçilerin çeşitli mahsuller ekip biçtikleri görülmüsşür [27].

Pedrero ve arkadaşları (2010) tarafindan İspanya'da yapılan bir çalışmada arıtılmış atıksuların turunçgil ağaçlarına uygulanmasının etkileri değerlendirilmiştir. İki farklı arıtma tesisinde arıtılmış atıksu ile sulanan iki arazi karşılaş̧tırılmıştır. Araziler İspanya'nın güneydoğusundaki Murcia'da bulunmaktadır. Cartagena'da bulunan ilk arazi ikincil arıtma ile arıtılan su ile, Campotajar'da bulunan 2. arazi ise kuyu suyu ve üçüncül atıksu arıtma tesisinde arıtılan atıksu karışımı ile sulanmıştır [28]. Cartagena'nın arıtılıış atıksuyunda, elektriksel iletkenlik (EC), bulanıklık ve toplam çözünmüş katı madde (TDS) Campotejar'dakinden daha yüksektir. Bu sebeple kuyu suyuyla yapılan karışımın arıtılmış atıksuyun tarımsal kalitesini artırdığı gösterilmiştir. Her iki arazide de gözlenen yüksek elektriksel iletkenlik seviyeleri, yüksek klorür ve bor seviyesinden kaynaklanmaktadır. Murcia bölgesindeki arazide yetişen turunçgil yapraklarında toksik bir seviye gözlenmemiştir. Ancak, toprakta yüksek tuzluluk ve bor birikimi olduğu belirlenmiştir. Bu durumun Murcia bölgesinin arıtılmış atıksuyla sulanması sebebiyle meydana geldiği araştırmacılar tarafından düşünülmüştür. Campotejar'de yapılan çalışmada toprakta ve arıtılmış atıksuda fekal koliform, E. Coli ve helmint yumurtalarının varlığına rastlanmasa da Cartagena'daki arıtılmış atıksuda fekal koliform, sağlık standartlarının üstünde bulunmuştur. Her iki araziye de arıtılmış atıksuyun uygulanması, toprakta ölçülen makronütrientler ve organik madde miktarını arttırmamış, dolayısıyla atıksu bu çalışmadaki koşullar altında toprak için bir nütrient kaynağı olmamıştır [28].

Arıtılmış kentsel atıksularda bulunan ağır metallerin toprakta ve bitkilerdeki birikimileri Kalavrouziotis ve arkadaşları tarafından 2005 ve 2008 yıllarında yapmış oldukları çalışmalarda belirlenmiştir. Yunanistan'ın Agrinion bölgesinde soğan ve marul bitkileriyle gerçekleştirilen çalışmada [29]. Arıtılmış kentsel atıksu ve kuyu sulama suyu olmak üzere iki farklı su kaynağının etkileri değerlendirilmiştir. Arıtılmış atıksuyla sulanan marulun ve soğanın yetiştirildiği toprakta ve yapraklarında $\mathrm{Mn}, \mathrm{Zn}, \mathrm{Cu}$ ve $\mathrm{Fe}$ elementleri incelenmiştir. İki sebze türü arasındaki metal birikimleri incelendiğinde marulun soğana göre daha fazla birikim yaptığı görülmüştür. Marul toprağınında yaprağında olduğu gibi $\mathrm{Cu}$ elementi hariç daha fazla birikim yapmış olduğu belirlenmiştir. Kuyu sulama suyu altında elde edilen değerlerle karşılaştırıldığında bu değerlerin istatistiksel olarak anlamlı olmadığı bulunmuştur. $\mathrm{Bu}$ nedenle arıtılmış kentsel atıksuyun bu mahsullerin sulanmasında kullanılabileceği sonucuna varılmıştır [29].

Kalavrouziotis ve arkadaşları tarafından 2008'de yapmış oldukları çalışmada arıtılıış kentsel atıksu ve kuyu sulama suyu olmak üzere 2 farklı su kaynağının etkileri brüksel lahanası ve brokoli yetiştirmek için incelenmiştir. Ağır metallerin, makro ve mikro nutrient parametrelerinin bu iki sebzenin tomurcuk ve yapraklarındaki birikimleri incelenmiştir. Bitkilerdeki sonuçlar incelendiğinde iki sulama suyu arasında dikkate değer bir şekilde farklılık görülmemiştir. Ancak $\mathrm{Zn}, \mathrm{Cd}$ ve $\mathrm{Pb}$ gibi ağır metal konsantrasyonlarının normal bir büyüme için sınır değerler içinde olmalarına rağmen arıtılmış kentsel atıksuyla sulanan toprakta biriktikleri gözlenmiştir. Arııılmış atıksuyla sulanan bitkilerde Fe birikiminin brokolide, Ni ve Co'nun brüksel lahanasında daha yüksek olduğu görülmüştür [30]. Arıtılmış kentsel atıksularda bulunan ağır metallerin toprakta ve bitkilerdeki birikimileri Tablo 3'te verilmiştir.

Yapılan çalışmalar tatlı biber ve kırmızı acı biberin yapay sulak alanlarda arıtılan atıksu ile yetiştirilebildiğini göstermiştir. Ancak tatlı biberden elde edilen verim ile kırmızıbiberden elde edilen verim oldukça farklı bulunmuştur. En yüksek sayıda mahsul musluk suyu ve organik yetiştirme ortamı ile elde edilmiştir. Hidrokarbon bulaşmış sulama suyuyla sulanan bitkilerin hasadı verimsiz olmuştur. Sonuçlar, kırmızıbiberin arıtılmış atıksuyla sulanmasının nutrient konsantrasyonu açısından uygun olmadığını, konsantrasyonların bitki 
açısından yüksek olduğunu göstermiştir. Ayrıca, kırmızıbiberin verimliliği atıksu tüketiminden bağımsız bulunmuştur ve aşırı nütrient ve iz elementten dolayı daha fazla yaprak üretimi meydana gelmiş ve daha fazla su kullanımı gerekmiştir [26].

Tablo 3. Arıtılmış kentsel atıksularda bulunan ağır metallerin toprakta ve bitkilerdeki birikimileri [29, 30]

\begin{tabular}{|l|l|l|l|l|l|l|}
\hline $\begin{array}{l}\text { İzlenen } \\
\text { Metaller }\end{array}$ & $\begin{array}{l}\text { Marul } \\
\text { Toprağ1 } \\
(\mathrm{kg} / \mathrm{ha})\end{array}$ & $\begin{array}{l}\text { Soğan } \\
\text { Toprağ1 } \\
(\mathrm{kg} / \mathrm{ha})\end{array}$ & $\begin{array}{l}\text { Marul } \\
\text { Yaprağ } \\
1(\mu \mathrm{g} / \mathrm{g})\end{array}$ & $\begin{array}{l}\text { Soğan } \\
\text { Yaprağ } \\
1(\mu \mathrm{g} / \mathrm{g})\end{array}$ & Brüksel lahanası $(\mu \mathrm{g} / \mathrm{g})$ & Brokoli $(\mu \mathrm{g} / \mathrm{g})$ \\
\hline $\mathrm{Mn}$ & 42,1 & 30 & 177,5 & 17,5 & & \\
\hline $\mathrm{Zn}$ & 7 & 2 & 70,7 & 30,2 & & \\
\hline $\mathrm{Cu}$ & 2 & 31 & 15,3 & 6,87 & & 1022 (tomurcuk) \\
\hline $\mathrm{Fe}$ & 31,7 & 27,6 & 165,6 & 38,6 & 388 (tomurcuk) & 4,15 (yaprakta) \\
\hline $\mathrm{Ni}$ & & & & & 6,17 (yaprakta) & 2,53 (yaprakta) \\
\hline $\mathrm{Co}$ & & & & & 2,70 (yaprakta) & \\
\hline
\end{tabular}

Amerika Birleşik Devletleri Kaliforniya Eyaleti'nde yapılan çalışmada Pomona ileri Atıksu Arıtma Tesisi'nde bulunan bir besleme tankı, su ürünleri yetiştirme havuzları ve bir yapay sulak alandan oluşan kombine tesis kullanılarak Çin su 1spanağı ve tonlarca su sümbülü yetiştirilmiştir. Gür yapraklı Çin su 1spanağı (Ipomea aquatica), yüksek besin değerine sahiptir ve su kalitesinin etkilerini değerlendirebilmek için daha önce farklı çalışmalarda kullanılmış yenilenebilir bir sebzedir. Su sümbülü ise düzenli olarak yetiştirilerek toprakların iyileştirilmesinde kullanılmaktadır. Bu sistem ile tarımsal ürün yetiştiriciliği yaparken aynı zamanda \% 97'nin üzerinde nütrient giderimi de sağlanmıștır ve atıksuyun \% 50'si tekrar kullanılmıştır. Atıksuyun geri kalan kısmı ile yeraltı suları beslenmiştir. Arıtma Tesisi birincil çökeltme tankı, anoksik ve aerobik havalanma tankı, ikincil çökeltme tank1, filtrasyon ve klorlama ünitesinden oluşmuştur [31].

İran'da atıksu arıtma tesisine sahip 253 endüstriyel organize sanayi bölgesinin 217'si İran'ın kurak bölgelerinde kurulmuştur. Bunların hemen hemen hepsi su kaynaklarından yoksundur, dolayısıyla arıtılmış atıksu, yeni güvenilir su kaynağı olarak düşünülmektedir. İkincil arıtılmış atıksuyun geri dönüşümü ve yeniden kullanımı 2005 yılından beri sulama amaçlı olarak kullanılmaktadır. Şimdiye dek ortalama olarak $24800 \mathrm{~m}^{3} /$ gün kapasiteye sahip 37 tane arıtma tesisinin çıkış suyunda aylık kontrol için yalnızca pH, BOİ, KOİ ve TAKM parametrelerine bakılmakta ve arıtılan atıksu direkt olarak ya da ham atıksuyla karıştırılarak sanayi bölgelerinin bahçe sulamalarında kullanılmaktadır [32].

Arttılmış Atıksuyla Tarımsal Sulamada Dikkat Edilmesi Gerekenler

Bir arazide normalde yetişebilecek ürünlerden hangisi ya da hangilerinin seçileceği, sulama suyu olarak kullanılacak olan atıksuyun kalitesi dikkate alınarak kararlaştırılmaktadır. Atıksular ile yetiştirilebilecek ürünler aşağıda verilmektedir [33]:

Yem bitkileri (Ot ve çim çeşitleri, yonca ve benzeri yem bitkileri)

Insani besin değeri olmayan bitkiler (Çeşitli ağaçlar, ormanlar, süs bitkileri ve çiçekler)

Arazi bitkileri (Mısır, darı, buğday, arpa, çavdar, pirinç, baklagiller, akdarı, şeker pancarı, pamuk, keten, yağ bitkileri (ayçiçeği, kolza, kanola), tütün)

Sebzeler (Domates, patates, salatalık, enginar, brokoli, 1spanak, soya fasulyesi, fasulye, kabak, karnabahar, bamya)

Meyveler (Turunçgiller, elma, çilek, üzüm, muz)

Kentsel atıksular sulamada kullanılırken; 1) Toksik metallerin toprak ya da bitkilerde birikiminin önüne geçmek için atıksuyun periyodik olarak laboratuvar kontrolünden geçmesi gerekir, 2) Dünya Sağlık Örgütü (WHO) 'nün izin verdiği sınır değerlere uyan mikrobiyal yüklemeye sahip çıkış suyu elde etmek için atıksu arıtma yöntemleri geliştirilmelidir [28]. İz elementlerin sulamada önerilen maksimum konsantrasyonları Tablo 4' te verilmiştir. Su kıtllğg ile bilinen ülkelere örnek olarak İsrail'de insanlar tarafindan tüketilen mahsullerin sulanmasında kullanılan atıksuda toplam BOİ $_{5}$ miktarının $15 \mathrm{mg} / \mathrm{L}$, çözünmüss BOİ $_{5}$ konsantrasyonunun 10 mg/L, AKM'nin $15 \mathrm{mg} / \mathrm{L}$ olması gerekmektedir [34]. Çözünmüş oksijen miktarının $5 \mathrm{mg} / \mathrm{L}$, kalıntı klor miktarının ise $0,5 \mathrm{mg} / \mathrm{L}$ standardını sağlaması gerekmektedir. Bu değerlerin Dünya Sağlık Örgütü’nün sulamada kullanılan atıksular için yerine getirilmesini istediği değerlere göre daha yüksek olduğu görülmektedir.

Atıksuyla sulamadan kaynaklı sağlık riskleriden en çok rastlananları çiftçilerin ve tüketicilerin parazit enfeksiyonlarını da içeren patojenlere (protozoa, virüs ve bakteriler) maruz kalması, organik ve inorganik iz 
elementlerin birikim yapması ve deri ve tırnak problemleridir. Ancak bu sağlık risklerine rağmen çiftçiler arıtma maliyetlerini karşılayamamaktadırlar [36].

Tablo 4. Sulama sularında izin verilebilen maksimum ağır metal ve toksik elementlerin konsantrasyonları

\begin{tabular}{|c|c|c|}
\hline PARAMETRE & $\begin{array}{c}\text { Uzun dönemli } \\
\text { kullanım (mg/L) } \\
{[15,35]}\end{array}$ & $\begin{array}{c}\text { Kısa dönemli } \\
\text { kullanım (mg/L) } \\
{[35]}\end{array}$ \\
\hline Alüminyum & 5,0 & 20 \\
\hline Arsenik & 0,10 & 2,0 \\
\hline Berilyum & 0,10 & 0,5 \\
\hline Bor & 0,75 & 2,0 \\
\hline Kadmiyum & 0,01 & 0,05 \\
\hline Krom & 0,1 & 1,0 \\
\hline Kobalt & 0,05 & 5,0 \\
\hline Bakır & 0,2 & 5,0 \\
\hline Florür & 1,0 & 15,0 \\
\hline Demir & 5 & 20,0 \\
\hline Kurşun & 5 & 10,0 \\
\hline Lityum & 2,5 & 2,5 \\
\hline Manganez & 0,2 & 10,0 \\
\hline Nikel & 0,2 & 2,0 \\
\hline Selenyum & 0,02 & 0,02 \\
\hline & &
\end{tabular}

\subsection{Arıtılmış Atıksuların Su Ürünleri Yetiştiriciliğinde Kullanımı}

Atıksuların su ürünleri için kullanabilmesinin ön şartı sulamada olduğu gibi mikrobiyal kirlilik parametrelerinin sınır değerler altında olmasıdır. Atıksu ile beslenerek yetiştirilen su ürünlerinin insan ve hayvan beslenmesinde kullanılması birçok çalışma ile araştırılmışıı: [37, 38, 39, 40, 41, 42, 43, 44, 45, 46]. Bu alanda kullanılan balık türlerinin çoğunlukla; Rohu balığı (Labeo rohita), Hint sazanı (Catla catla), Mrigal carp (Cirrhinus mrigala), Tilapia (Oreochromis mossambicus) ve Sazan balı̆̆ (C. carpio), Micropterus, Kocabaş Sazan (Aristichthys nobilis), Gümüş sazanı (Hypophthalmichthys molitrix), Kadife balı̆̆ı (tinca tinca),öpüşen gurami (Helostoma temminckii),Tinfoil barb (Puntius gonionotus) ve Dev gurami (Osphronemusg oramy)'dir. Bu balık türleri genel olarak ılıman kökenli ve sıcak sularda yaşamaktadırlar. Ancak, yıl boyunca mevsimsel olarak düşük sıcaklıklara sahip iklimlerde hayatta kalabilmektedirler [47].

Atıksu beslemeli balık yetiştiriciliğine uyumu gözlemlemek için birçok çeşitte balık türü test edilmiştir. 1904 yılında, öncelikli olarak dipten beslenen sazan balığı (Cyprinus Carpio), süzerek beslenen alabalık (Coregonus $s p$.), etobur bir tür olan uzun levrek, sudak (Stizostedion), denizalası (Salmo trutta), gökkuşağı alabalı̆̆ (Oncorhynchus mykiss)'nı denemiştir. 1921 yılında, turnabalığı (Esox lucius)' na ek olarak sazan balı̆̆ı, karabalık (Tinca tinca), gökkuşağı alabalığı ve sudak balığını tavsiye etmiş̧ir. Daha sonra yapılan araştırmalar ve kazanılan tecrübeler sonucu belirli aralıklarla yükselen sıcaklıklar ve çözünmüş oksijendeki azalmadan dolayı sazan balığı ve karabalık en iyi türler gibi görülmüştür. Gökkuşağı alabalığı, oksijen değerleri kritik olmadığı zaman hayatta kalabilmektedir. Diğger yandan bu tür sıcaklığa karşı en dirençli ve toleranslı balıktır [48]. Sazan balığı (Cyprinus Carpio) ve karabalık (Tinca tinca) atıksu beslemeli havuzlarda yetiştirilen en yaygın iki balık türü olarak literatürde yer almıştır [48].

Hindistan'daki "Kalküta atıksu beslemeli sulakalanları" ve Münih arıtılmış atıksu beslemeli balıkçılık tesisi önemli örneklerdir. Hindistan'da toplamda 12000 ha'ı kaplayan 130' un üzerinde atıksu beslemeli balık tutma alanı vardır. 1930 yılından beri işletilen Kalküta Sulak Alanları dünyanın en büyük atıksu balıkçılığı yapılan tesisidir. Yaklaşık 4000 ha'ı kaplayan ve 4000 aileye iş imkanı sağlayan bu havuzlarda çeşitli sazan balıkları ve Tilapia (Oreochromis mossambicus) türü yetiştirilmektedir. Buradan yakalanan balıklar Kalküta'nın tüketilebilir balıklar için olan pazar talebinin \%10' unu karşılamaktadır. Yapılan bir araştırmada Kalküta'daki atıksularda ağır metallere rastlanmıştır ve bu bölgedeki marketlerde satılan balık ve sebzelerde kırsal bölgelerde yetiştirilenlere nispeten yüksek seviyelerde kurşun, kadmiyum ve kroma rastlanmıştır [49, 50].

Atıksu beslemeli su ürünleri yetiştiriciliği, sürekli artan insan nüfusu tarafindan üretilen atık su miktarının konvansiyonel arıtma tesislerinin kapasitesinin üstünde olması nedeniyle gelişmekte olan ülkelerde daha büyük önem kazanmaktadır. Hindistan'da günlük 15 milyar litrelik evsel atıksudan yaklaşık 1,3 milyon \$ değerinde 90 
ton $\mathrm{N}, 32$ ton $\mathrm{P}$ ve 55 ton $\mathrm{K}$ geri kazanılabilmektedir. Atıksularla beslenen balıklar biyokütle haline dönüştürülerek gelişmekte olan ülkelerdeki milyonlarca insana istihdam olanakları da sağlanmaktadır [51].

Arıtılmış atıksularla balık yetiştiriciliğine Ülkemizde de bazı örnek çalışmalar mevcuttur. Çanakkale'de bulunan İÇDAŞ Çelik Enerji Tersane ve Ulaşım Sanayi Tesisi'nde ortalama 22-24 derece sıcaklığa sahip günlük yaklaşı $6000 \mathrm{~m}^{3}$ soğutma suyu tekrar denize deşarj edilmek yerine balık yetiştiriciliğinde kullanılmaktadır. Bu amaçla kurulan havuzlarda yetiştirilen 90 bin çupra ve levreğin, 9 ayda 400-500 gram ağırlığa ulaşarak ilk hasadın ardından balıkçılara satıldığı bilgisine ulaşılmıştır [52]. Bir diğer örnek de Konya Şeker Fabrikası'nda kondense suyunun balık yetiştiriciliğinde kullanımıdır. Fabrikaya bağlı Çumra Şeker Entegre Tesisleri'nde üretim sürecinde ortaya çıkan kondense suyu, ekstra enerji harcanarak soğutulmak yerine o suyun isısından yararlanarak Amerika'dan ithal edilen 150000 adet Tilapia balığının yetiştirilmesinde kullanılmaktadır. Özellikle tropik ve subtropik iklim balığı olarak bilinen Tilapia balığı, sıcaklığı $25-28^{\circ} \mathrm{C}$ olan sularda yaşamaktadır ve et verimi ve kalitesi yüksek olan bu türün et rengi pembe-kırmızı-beyaz olduğu için de albenisi yüksektir. Yediği yemin yaklaşık 2/3'ünü ete dönüştüren bu balık türünün üretilmesi için kurulan tesis, mevcut kapasitesi ile yıllık 200 ton üretim gerçekleştirmeyi hedeflemektedir. 1,2 milyon dolarlık yatırım yapan tesisin 5 yılda kendisini amorti edeceği tahmin edilmektedir [53].

\subsection{Arıtılmıș Atıksuların Endüstride Kullanımı}

Endüstriyel yeniden kullanımda atıksular, endüstriyel atıksuların fabrika için geri dönüşümünden ve/veya kentsel su arıtma tesislerinden sağlanabilmektedir. Çelik sanayii, bira sanayii ve elektronik sektörü gibi diğer endüstriler çıkış suyu deşarj standartlarını sağlamak için atıksularını arıtmakta ve geri kazanmaktadırlar [54].

Arıtılmış atıksuların endüstriyel prosesler için uygunluğu üretilen ürünlere bağlıdır. Örneğin elektronik sanayii, devre kartı ve diğer elektronik bileşenlerin yıkanması için neredeyse saf su kalitesinde su gerekmektedir. Öte yandan tabakhane sanayiinde nispeten düşük kalitede su kullanılmaktadır. Tekstil ürünleri, kağıt hamuru ve kağıt ve metal üretimi için gereksinimler orta kalitededir. Böylelikle arıtılmış atıksuların endüstriyel yeniden kullanımının geçerliliğini araştırırken proses suyundaki spesifik gereksinimler önemlidir [55]. Arıtılmış atıksular endüstriyel amaçla buharlı soğutma suyu, kazan besleme, proses ve tesisi zeminini bakımında kullanılmaktadırlar. Bu kullanımlar arasında soğutma suyu en çok kullanılan endüstriyel uygulamadır. Çoğu sanayi tesisinde soğutma işlemi tek başına büyük bir su ihtiyacı yaratmaktadır. Küçük bir petrol rafinerisi ya da 250 MW'lık bir kamu enerji santrali soğutma sistemini devirdaim ettirmek için 44-88 L/s kadar ilave suya ihtiyaç duymaktadır. Dünya çapında soğutma için arıtılmış atıksu kullanan sanayi tesislerinin çoğunluğunu kamu enerji santralleri oluşturmaktadır. Tablo 5'te Farklı endüstriler için proses suyu kalite standartları verilmiştir [55].

Arıtılmış atıksuların kağıt ve kağıt hamuru sanayiinde yeniden kullanımı, kağıdın maliyeti ve sınıfının bir fonksiyonudur. Yüksek kaliteli kağıt daha kaliteli su gerektirmektedir. Suda bulunan metal iyonları ve renkli kirleticiler gibi safsızlıklar üretim kalitesini bozabilmektedir. Kimya endüstrisi için su kalite gereklilikleri üretime göre büyük ölçüde değişiklik göstermektedir. Genel olarak nötral pH aralığında olan, kısmen yumuşak, düşük bulanıklığa ve düşük askıda katı madde içeriğine sahip sular gerekmektedir. Çözünmüş katı madde ve klorür içeriği çok önemli değildir [55].Tekstil üretiminde kullanılan suların kağıt sanayiine benzer olarak leke bırakmaması, dolayısıyla düşük bulanıklık, renk, demir ve manganez içeriklerinin olması gerekmektedir. Sertlik, sabun kullanılan bazı proseslerde soruna yol açabilmekte ve nitrat ve nitrit, boyamada problemlere sebep olabilmektedir [55].

2004 yılında bir halı fabrikasına ait baskı ve asit boyama atıksularının arıtımı ve geri kazanımına yönelik yaptıkları araştırmada, baskı boyama atıksuyunun kalitesi, British Textile Technology Group tarafından sentetik iplik boyama işlemi için belirlenmiş olan geri kazanım kriterleri ile karşılaştırılmış ve bunun sonucu baskı boyama atıksularından alum ile kimyasal çöktürme sonrası nanofiltrasyon (NF) ve ultrafiltrasyon (UF) prosesleri ile elde edilen süzüntü sularının boyama işleminde yeniden kullanılabilecek kalitede olduğu belirlenmiştir. Asit boyama atıksuları için ise mikrofiltrasyon (MF) ön işleminin ardından uygulamalı üç kademeli NF işlemi ile geri kazanım kriterlerinin sağlandığı görülmüştür [33]. Petrol ve kömür ürünleri üretim prosesleri, nispeten daha düşük kalitedeki suları kullanabilmektedir.

Endüstriyel geri kullanımda, atıksuların arıtım yöntemlerinin endüstri tipine bağlı olarak çok farklı olduğu görülmektedir. Ancak proses açısından birbirine uyumulu ve fiziksel olarak yakın bulunan tesislerde endüstriyel simbiyoz yaklaşımı ile birbirlerinin atıksularını kullanma olanakları araştırılmalıdır.

\subsection{Diğer Sektörlerde Kullanımı}

$\mathrm{Su}$ kaynaklarının ciddi boyutlarda yetersiz olduğu bölgelerde ileri arıtma teknikleri kullanılarak arıtılan atıksular, içme suyu olarak kullanılabilmektedir. Bu kullanım seçeneği diğerlerine nispeten çok daha fazla özen 
ve dikkat gerektirmekte, hata yapıldığında hızlı bir şekilde ciddi sorunlara yol açabilmektedir. Çok ihtiyaç duyulmadığı sürece başvurulmamalıdır. Amerika Birleşik Devletleri Çevre Koruma Ajansı'nın 2004 yılında basılmış olan Evsel ve Endüstriyel Atıksuların İçme Suyu Olarak Kullanımı Uygulamaları dökümanında Avustralya, Namibya, Singapur, Meksika ve Amerika Birleşik Devletleri'ndeki Kalifornia ve Virjinya gibi bazı eyaletlerde kentsel atıksu arıtma tesisi çıkış suları yüzeysel veya yeraltı su kaynağına deşarj yapıldıktan ve yeniden arıtıldıktan sonra içme suyu standart değerlerini karşılaması durumunda kullanılmakta olduğu belirtilmiş̧ir [35]. Blöchar ve arkadaşları tarafindan 2002'de yapılan bir çalışmada pilot ölçekli ön çalışmalardan sonra meyve suyu fabrikalarında harcanan proses suyundan içme suyu üretimi yapan bir hibrit proses geliştirilmiştir. Evsel/kentsel ve endüstriyel atıksuların içme suyu olarak kullanımları sırasında, mikrofiltrasyon, ters ozmoz, ultraviyole ışıılarla (UV) ya da ozonlama ile dezenfeksiyon gibi ileri arıtma uygulamaları mevcuttur [56].

Tablo 5. Farklı endüstriler için proses suyu kalite standartları [55]

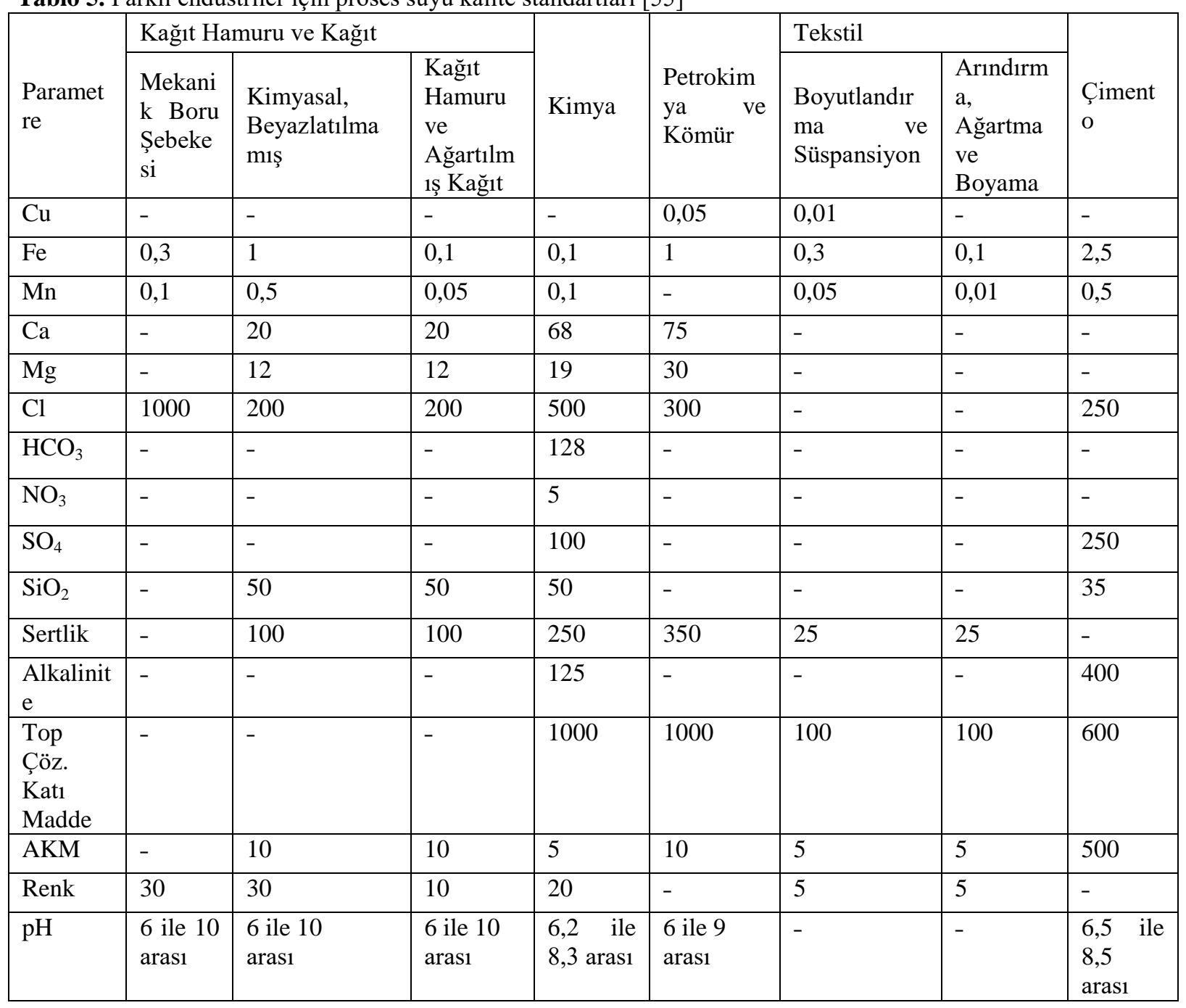

Sallanko ve Haanpää tarafından 2006 yılında Finlandiya'nın Kuusamo şehrinde yapılan bir çalışmada Ruka atıksu arıtma tesisinden çıkan arıtılmış atıksular yapay kar yapımında kullanılmıştır [57].

Arıtılmış atıksudan yapılan kar; doğal kara ya da kayak alanlarında yapılan yapay kara göre daha fazla kirletici (organik maddeler, askıda katı madde) içermektedir ve yapay karın yoğunluğu, kristal şekli ve boyutu doğal kara göre farklılık göstermektedir. Yapılan çalışmada kar için kullanılan sudaki kirletici konsantrasyonları Tablo 6'da gösterilmiştir [57].

Atıksuların tarımsal alanların dışında golf sahaları ve bahçelerin de sulanmasında kullanılmasına da örnekler mevcuttur. Amerika Birleşik Devletleri'ndeki golf sahalarının \%12'sinde sulama için arıtılmış atıksu yeniden kullanılmaktadır. Golf sahalarındaki su tüketimi iklim, topografya, toprak, su tahliyesi, rüzgar, güneş etkisi ve golf sahasının boyutları ve tasarımı gibi değişkenlere bağlı olarak çeşitlilik göstermektedir. Ortuno ve arkadaşları 
tarafından 2014 yılında yapılan ve Amerikada'daki golf sahalarının \%15'ini kapsayan bir çalışmaya göre 18 delikli bir golf sahasının sulama ihtiyacı kuzeydoğuda yıllık $52000 \mathrm{~m}^{31}$ ten çöl bölgelerinde $566000 \mathrm{~m}^{31} \mathrm{e}$ kadar değişiklik gösterebilir. Avrupa'da yapılan golf sahalarıyla ilgili araştırmada Fransa'daki standart bir golf sahasının yıllık su tüketiminin ülkenin güneyinde yıllık 150000-200000 $\mathrm{m}^{3}$ arasında değiştiğini göstermiştir. Kuru ve 1 lık iklimlerde çok daha yüksek değerler bulunabilir. Akdeniz ülkelerinde ise bu tüketimin pirinç havzaları tüketimine benzer bir şekilde yıllık 500000-700000 $\mathrm{m}^{3}$ arasında değiştiği tahmin edilmektedir [58]. 2002 'de Florida'nın bir vilayeti olan Manatee County'nin toplamda $1500 \mathrm{~L} / \mathrm{s}$ kapasiteye sahip üç arıtma tesisi, yaklaşık olarak $446 \mathrm{~L} / \mathrm{s}$ arıtılmış atıksu sağlamıştır. Bu su, golf sahalarının, parkların, okulların, 600 ha'lık glayöl (Gladious sp.) tarlasının ve yaklaşık olarak 2400 ha'lık karışık (turunçgil tarlaları, otlaklar) tarım arazisinin sulanmasında kullanılmıştır [58].

Tablo 6. Kar yapımı için kullanılan sudaki kirletici konsantrasyonları [57].

\begin{tabular}{|l|l|}
\hline Parametreler & Konsantrasyonlar \\
\hline Biyolojik Oksijen İhtiyacı (BOİ) & $12 \mathrm{mg} / \mathrm{L}$ \\
\hline Kimyasal Oksijen İhtiyacı (KOİ) & $20 \mathrm{mg} / \mathrm{L}$ \\
\hline Toplam Fosfor & $120 \mathrm{mg} / \mathrm{L}$ \\
\hline Toplam Azot & $80 \mathrm{mg} / \mathrm{L}$ \\
\hline $\mathrm{pH}$ & 7,3 \\
\hline Renk & $80 \mathrm{mg} \mathrm{Pt/L}$ \\
\hline Bulanıklık & $5 \mathrm{NTU}$ \\
\hline Askıda katı madde & $18 \mathrm{mg} / \mathrm{L}$ \\
\hline
\end{tabular}

İspanya Doğal Sulama Planında 1100 milyar $\mathrm{m}^{3}$ 'lük arıtılmış atıksuyun golf sahaları sulamasında kullanılması zorunlu kılınmıştır. Candela ve ark tarafından İspanya'nın Girona şehrinde yapılan bir çalışmada İngiliz çimi (Lolium perenne)'ne sahip "Serres de Pals" golf sahaları, 2000 yılından 2003 yılına kadar kentsel arıtılmış atıksu ile sulanmıştır. Bu suyun kullanımıyla toprağın ve toprak altındaki akiferin etkilenip etkilenmediğini değerlendirmek için, birkaç ay boyunca belli periyotlarla atıksu arıtma tesisinde stabilizasyon havuzundan, yeraltı suyu ve zemin profilinden numuneler alınmıştır. Çalışma sonunda golf sahalarının tarımsal yönetimi ve arıtılmış kentsel atıksuyun kalitesi ve bölgenin toprak ve akifer kimyasal karakteristiği sulamayla değiştiği gözlenmiştir. Kalsiyum ve magnezyum konsantrasyonları değişmemiş ancak, yeraltı suyunun sertliği, doymamış tabakadaki katyonik değişimden dolayı artmıştır [59]. Diğer yandan Avrupa'da arıtılmış atık suların yeniden kulanımı şu sıralar çok yaygın bir uygulama değildir. Akdeniz ülkeleri için kişi başı kullanım açısından temel sorun su kıtlı̆̆ı değil, suyun doğru yerde, doğru zamanda ve gereken miktarda kullanıma uygun hale getirilmesidir [58].

\subsection{Gri Suların Yeniden Kullanımı}

Kurak ve yarı kurak bölgelerde su ihtiyacı için alternatif bir kaynak olan [60] gri su; tuvalet haricinde, banyo, duşluk, el yıkama lavaboları, çamaşır makineleri, bulaşık makineleri ve mutfak lavabolarını da kapsayan kentsel atıksular olarak tanımlanmaktadır [61]. Sabun ve deterjanlar, gri suda bulunan en önemli kirleticilerdir. Ancak insan dışkıları ve tuvalet kağıtlarını içermediğinden genellikle kentsel atıksulardan daha az kirlidir [62].

Gri su üretim sistemleri diğer alternatif su kaynakları (yağmur suyu vs.) ile birleştirildiği zaman içilebilir olmayan su temini için önemli bir girdi olabilmektedir [61]. İnsanlar genel olarak gri suyun, özellikle tuvalet sifonu için kullanımını ilginç ve güvenilir bir yöntem olarak görerek, net bir şekilde kabul etmektedir. Suyla direk temas gerektiren aktivitelerde suyun kalitesi konusunda güvenilmezlik durumu ortaya çıkmaktadır. Bu nedenle gri suyun kullanımı toplum tarafından kabul edilmeyebilmektedir. Gri suyun daha geniş amaçlı kullanımı için yapılması gerekenler, hükümetten mali destek alınması, kullanıcı dostu bilgi paketleri ve eğitim programları yapılması ve düşük-maliyetli evsel gri su arıtım ünitelerinin geliştirilmesidir [61]. Gri suyun yeniden kullanımının sürdürülebilir olması için göz önünde bulundurulması gereken bazı önemli parametreler; $\mathrm{pH}$, elektriksel iletkenlik, askıda katı madde, ağır metaller, fekal koliform, E. Coli, çözünmüş oksijen, BOİ, KOİ, toplam azot ve toplam fosfor miktarıdır. Gri suyun kimyasal ve fiziksel karakteristikleri kullanılan deterjanın türü, yıkanan materyallerin türü, bölge sakinlerinin yaşam tarzı gibi birçok faktöre bağlı olarak değişiklik göstermektedir. Pinto ve arkadaşları, 2008 yılında yaptıkları bir araştırmada mutfak atıksuyunun en yüksek, el lavabosu ve duşluklarından kaynaklanan atıksuyun ise en düşük elektriksel iletkenliğe sahip olduğunu bulmuşlardır. Ayrıca, evsel kullanımdan kaynaklanan gri suların pH aralığının ise 5,0-8,7 aralığında değişirken, daha bazik pH ise 9,3-9,5 aralığında çamaşır makinesi kaynaklı gri suda tespit edilmiştir [62]. 
Gri su arıtımın da suyun karakteristiğine bağlı olarak istenilen standartlara ulaşmak için fiziksel, kimyasal ya da biyolojik arıtma teknolojileri kullanılmaktadır. Çöktürme ve filtrasyon işlemleri fiziksel arıtma teknolojisi olarak kullanılmaktadır. Filtrasyon işlemi genellikle biyolojik ya da kimyasal arıtma ünitelerinden önce ön arımı sağlamak amacıyla kullanılmaktadır. Filtrasyon işleminde ön arıtım olarak kum filtre, kaba filtre ya da membran filtre kullanılarak AKM ile bazı organik maddeler ve patojenler giderilebilmektedir. Bazı çalışmalarda hem partikül hem de nutrient gideriminin sağlandığı kimyasal arıtma teknolojileri kullanılmaktadır. Kimyasal arıtma teknolojileri olarak elektrokoagülasyon, fotokatalatik oksidasyon, iyon değiştiriciler ve granüler aktif karbon uygulanmaktadır. Ancak kimyasal kullanımını engellemek için biyolojik arıtma teknolojileri ile de gri su arıtımı sağlamak mümkündür. Gri suyun biyolojik arıtımında yapay sulak alan $(\mathrm{CW})$, döner biyolojik reaktör (RBC), ardışık kesikli rektör (SBR), membran biyoreaktörü (MBR) teknolojileri kullanılmaktır. Membran biyoreaktörü dışında ki diğer biyolojik proseslerde gri su geri kazanım standartlarını sağlayabilmek için ön arıtım olarak filtrasyon veya çöktürme işlemi, son arıtımda UV veya klor ile dezenfeksiyon işlemi uygulanmaktır [63].

Gri su arıtılsa bile sulama amaçlı ya da direkt temas için kullanırlırken famasotikler ve diğer mikrokirleticiler açısından mutlaka incelenmelidir. Tablo 7'de Gri suların yeniden kullanıldığı ülkeler ve kullanım alanları sunulmuştur.

Tablo 7. Gri suların yeniden kullanıldığı ülkeler ve kullanım alanları

\begin{tabular}{|l|l|}
\hline Ülke & Kullanım Alanı \\
\hline İsrail [60] & Spor salonlarında \\
\hline Hindistan [64] & Tuvalet sifonu ve tarımsal sulama \\
\hline Avustralya [21] & Evlerde Gri su sistem kurulumu için indirim uygulaması \\
\hline $\begin{array}{l}\text { ABD Arizona Eyaleti } \\
\text { [35] }\end{array}$ & Evlerde ve huzur evlerinde gri su sistem kurulumu için indirim uygulaması \\
\hline $\begin{array}{l}\text { Kore, Çin, Güney } \\
\text { Kıbrı, Japonya [60] }\end{array}$ & Evlerde Gri su sistem kurulumu için indirim uygulaması \\
\hline Japonya [60,65] & $\begin{array}{l}\text { 30000 mnin üzerinde alana sahip ya da günlük 100 m }{ }^{3} \text { su yeniden kullanım } \\
\text { potansiyeline sahip binalar için gri su sistemleri kurulumu zorunludur ve } \\
\text { Tokyo'da tuvalet sifonu için kullanılan arıtılmış atıksu miktarı yaklaş1k 970000 } \\
\text { m3/yıl' dır. }\end{array}$ \\
\hline İspanya [60,68] & $\begin{array}{l}\text { Barcelona yakınlarındaki Sant Cugat del Valles ve Catalonia'daki diğer } \\
\text { belediyeler de çok katlı binalarda gri su yeniden kullanımı için düzenlemeler } \\
\text { getirmiştir. }\end{array}$ \\
\hline Almanya [65] & $\begin{array}{l}\text { İnsan sağlığ1 ve çevreyi korumayla ilgili yeniden kullanım kriterleri ilk olarak } \\
\text { 1988 yılında Berlin şehrinde kurulan gri su pilot tesisleri için hazırlanmıştır. }\end{array}$ \\
\hline Lübnan [64] & Tarımsal sulama \\
\hline Filistin [64] & Tarımsal sulama \\
\hline
\end{tabular}

\section{Gri Suyun Yeniden Kullanım Maliyeti}

Atıksuların arıtılmasının ve yeniden kullanımının maliyetlerinin kimin tarafından karşılanacağı kullanımın verimliliği açısından önemlidir. Maliyet, kullanım amacına göre kaynağın nihai kalitesi, güvenilirliği ve çevresel ve sağlık etkilerine bağlı olarak değişmektedir. Arıtma maliyetlerinin yanı sıra, işletme maliyetleri, analitik maliyetler ve pazarlama maliyetleri de hesaba katılmalıdır [23]. Oron ve arkadaşlarının 2001 yılında yapmış oldukları çalışmada bir gri su yeniden kullanım sisteminin kurulumunun yıllık 240-310 \$ arasında olduğu belirtilmiştir. Ortalama 5 ferde sahip bir aile için yıllık maliyetin kişi başı 0,82-1,06 \$ olmaktadır. Bu maliyet kısa sürede amorti edilebilmektedir [60].

Sistemler için ilk yatırım maliyeti işletmenin büyüklüğüne göre değişim göstermektedir. Sistem büyüdükçe daire başına düşen maliyet azalmaktadır. İşletme maliyeti; bakım, tamir ve kontrol, enerji tüketimi ücretini kapsamaktadır. Tamir, bakım ve onarım masrafları seçilen teknolojiye bağlıdır. Basitçe yapılandırılmış bir işletme için genel olarak her yıl ilk yatırım maliyetinin \% 1'i yeterlidir; makineler/ teknik ekipmanlar için ise her yıl ilk yatırım maliyetinin \% 4 ü gibi düşünülmektedir. Gri suyu arıtmak için gerekli olan enerji, kullanım suyunun hidroforla sisteme basılması ve şebeke suyu takviyesi dâhil, kullanılan teknolojiye bağlı olarak $1 \mathrm{~m}^{3}$ kullanım suyu için 1,5 ile $3 \mathrm{~kW}$ arasındadır [63]. 


\section{ARITILMIŞ ATIKSULARIN YENIDEN KULLANIMINA HALKIN GÖRÜŞÜ}

Suyun yeniden kullanılırlığını toplum tarafından kabul edilebilirliğini etkileyen pek çok faktör vardır. Su yeniden kullanım projeleri de diğer su ve kanalizasyon projeleri gibi toplumun mali durumunu, çevresel sonuçlarını etkileyen ve sermaye gerektiren projelerdir. Toplum üyeleri sağlık konusu açısından kuşku duyup endişelenebilmektedirler. Bu sebeplerden dolayı halka danışma ve vatandaşlarla anlaşmaya gitme, su yeniden kullanım projelerinin yönetimi ve gelişimi açısından önemlidir [66]. Daha önceki yıllarda yapılan araştırmalar atıksu yeniden kullanımının davranışsal olarak kabul edilebilirliğini etkileyebilen faktörleri risklerinin algılanması, tiksinme faktörü, geri dönüştürülen suyun spesifik kullanımları, geri dönüştürülen suyun kaynağı, güven ve tecrübe, çevreye bakış açısı, çevresel adalet sorunları, geri dönüştürülen suyun maliyeti, sosyodemografik faktörler şeklinde sıralamışlardır [66].

Büyükkamacı ve Alkan tarafından 2013'te yapılan bir anket araştırmasında insanlara sorulan "Sizce atıksuyun hangi alanda kullanımı en uygun alternatiftir?" sorusuna verilen cevaplar arasında tuvalet sifonları, inşaat yapı işleri ve yol yıkama gibi insan temasını gerektirmeyen uygulamalar en fazla seçilen seçenekler olmuştur [67].

\section{SONUÇ}

Literatür derlemesi şeklindeki bu çalışma sonucunda kuraklık açısından baskı altında olan bölgeler başta olmak üzere arıtılmış evsel ve endüstriyel atıksuyun dünyanın pek çok yerinde tarımda, su ürünleri yetiştirmede, endüstride, evsel ve rekreasyonel amaçlar gibi pek çok amaçla kullanıldığı görülmüş̧ür.

Toksik maddeler içeren atıksuların sulama ve su ürünlerinde kullanımı sonucunda, metal birikimleri olduğu, toprağın ve yeraltı suyu kalitesinin bozulduğu ve toprakta tuzluluk problemleri yarattığı görülmüştür. Bu nedenle, temiz su ile karıştırılarak kullanılmasının uygun olduğu ve özellikle sulama ve su ürünleri yetiştiriciliği amaçlı direkt temas gerektiren kullanımlarda metaller, diğer toksik organik/inorganik kirleticiler açısından ve mikrobiyal kalitenin sağlık riski taşımayacak iyi düzeyde olması gerektiği görülmüştür. Kirleticilerin birikim seviyelerinin ve ürün verimlerinin bitki türüne göre değişmekte olduğu, kirletici konsantrasyonları standartları sağlasa bile birikim yapabildiği ve yüksek nütrient konsantrasyonlarının su ihtiyacını arttırdığı görülmüştür. Endüstriyel geri kullanımda, atıksuların arıtım yöntemlerinin ve gerekli olan su kalitesinin endüstri tipine bağlı olarak çok farklı olduğu ve gri suların tuvalet temizliğinde kullanımının su kaynaklarının verimli kullanımına son derece katkı sağlayacağı belirlenmiştir. Ancak bu araştırmada atıksuyun kullanım alanına göre halk sağlığı açısından ulusal ve uluslararası standart değerler ve parametrelere göre yasal mevzuatın geliştirilmesi gerektiği ve ilgili bakanlık tarafindan denetlenmesi gerektiği görülmüsstür. Diğer ülkelere kıyasla ülkemizde atıksuların yeniden kullanımı alanında yapılan uygulama sayısının az olduğu görülmüştür. Kentleşmenin, nüfus artışının ve iklim değişikliğinin etkisi ile ileride daha fazla su sıkıntısı çekebilecek ülkelerden birisi olan ülkemizde su yönetiminde atıksuların yeniden kullanımı çalışmaları devlet tarafından yapılabilecek teşviklerle yaygınlaştırılmalı ve havza yönetiminin bir parçası olarak görülerek su kaynaklarının korunması stratejilerinde yeralmalıdır. Ayrıca su tüketiminin çok olduğu halka açık tesislerde ve belirli alanın üzerinde olan binalarda gri su sistemleri kurulumunun zorunlu olması ülkemizin doğal kaynaklarının korunumu ve ekonomisinin geliştirilmesi açısından son derece faydalı olacaktır. Özellikle de "Büyükşehir Yasası" ile sınırları genişleyen belediyelerin arıtılmış atıksuların yeniden kullanımı çalışmalarına destek vermeleri daha kolay olacaktır.

\section{TEŞEKKÜRLER}

Bu çalışmadaki araştırmalara yardımlarından dolayı Çevre Mühendisi Hacer Demir'e teşekkürlerimi sunarim.

\section{KAYNAKLAR}

[1] AL-ISAWI, R.H.K., SCHOLZ, M., AL-FARAJ, F.A.M., "Assessment of diesel-contaminated domestic wastewater treated by constructed wetlands for irrigation of chillies grown in a greenhouse", Environmental Science and Pollution Research, 23, 25003-25023, 2016.

[2] WWAP. World Water Assessment Programme, the United Nations World Water Development Report 4: Managing Water under Uncertainty and Risk. UNESCO, 2012. 
[3] MULUK, Ç.B., KURT, B., TURAK, A., TÜRKER, A., ÇALIŞKAN M.A., BALKIZ, Ö., GÜMRÜKÇÜ, S., SARIGÜL, G., ZEYDANLI, U., "Türkiye'de Suyun Durumu ve Su Yönetiminde Yeni Yaklaşımlar: Çevresel Perspektif”. İş Dünyası ve Sürdürülebilir Kalkınma Derneği - Doğa Koruma Merkezi, 2013.

[4] ŞAHIN, B. "Küresel Bir Sorun: Su Kitlığı ve Sanal Su Ticareti", Yüksek Lisans Tezi, Hitit Üniversitesi Sosyal Bilimler Enstitüsü, Çorum, 2016.

[5] PINTIILIE, L., TORRES, C.M., TEODOSIU, C., CASTELlS, F., "Urban wastewater reclamation for industrial reuse: An LCA case study", Jounral of Cleaner Production, 139,1-14, 2016.

[6] DEMIR Ö., YILDIZ, M., SERCAN, Ü., ARZUM, C.Ş. "Atıksuların Geri Kazanılması ve Yeniden Kullanılması”, Harran Üniversitesi Mühendislik Dergisi, 2, 1-14, 2017.

[7] HERMANOWICZ, S.W., "Is Scarcity a Real Driver for Water Reuse?" University of California, Berkeley, CA 94720-1710, 2006.

[8] LAMAS, W.Q., FUJiSAWA, R.S. "Reuse of waste water from polyester fibres dyeing process by thermal fixation with dye acid base: Case study a Brazilian auto parts facility", Engenharia Térmica (Thermal Engineering), 8, 2, 42-49, 2009.

[9] NANSUBUGA, I., MEERBUG, F., BANADDA, N., RABAET, K. "A two-stage decentralised system combining high rate activated sludge (HRAS) with alternating charcoal filters (ACF) for treating", African Journal of Biotechnology, 14, 7, 593-603, 2015.

[10] KIVAİSİ, A. K. "The potential for constructed wetlands for wastewater treatment and reuse in developing countries: a review," Ecological Engineering, 16, 4, 545-560, 2001.

[11] AZIZ F., FARISSİ M. "Reuse of Treated Wastewater in Agriculture: Solving Water Deficit Problems in Arid Areas" Annals of West University of Timişoara ser. Biology,, 17,2, 95-110. 2014.

[12] JARAMILLO, M.L., RESTREPO, I. "Wastewater Reuse in Agriculture: A Review about Its Limitations and Benefits" Sustainability, 9,1734, doi: 10.3390, 2017.

[13] ÖZBAY, İ., KAVAKLI, M., "Türkiye'de ve Diğer Ülkelerde Arıtılmış Atıksuların Geri Kazanım Uygulamalarının İncelenmesi”, Çevre Sorunları Sempozyumu, Kocaeli. (2008).

[14] BiXİ, D., THOEYE, C., KONING DE, J., JOKSIMOVIC, D., SAVIC, D., WINTGENS, T., MELINN, T., "Wastewater reuse in Europe", Desalination, 187, 89-101, 2006.

[15] AATTUT. Atıksu Arıtma Tesisleri Teknik Usuller Tebliği, Resmi Gazete, Sayı: 27507, 2010.

[16] SSKKSYKHY. Sulama Sularının Kalitesi ve Kullanılmış Suların Yeniden Kullanılması Hakkında Yönetmelik Taslağı, Orman ve Su İşleri Bakanlığı, 2015.

[17] SANZ, L.A., GAWLIK, B. M., "Water Reuse in Europe Relevant guidelines, needsfor and barriers to innovation", Luxembourg: Publications Office of the European Union. 2014.

[18] DUMAN, H. "Arıtılmış Kentsel Atıksuların Sulamada Yeniden Kullanımı; Kayseri Atıksu Arıtma Tesisi Örneği”, Uzmanlık Tezi, Orman ve Su İşleri Bakanlığı, Su Yönetimi Genel Müdürlüğ̈̈, Ankara, 2017.

[19] SAGARAKIS, K.P., TSOUMANIS, P., CHARTZOULAKISS K., ANGELAKİS A.N., "Water Resources Status Including Wastewater Treatment and Reuse in Greece", Water International, 26, 2, 252-258, 2001.

[20] SRWR. Spanish Regulations for Water Reuse, Royal Decree 1620, 2007.

[21] EPA. South Australian Reclaimed Water Guidelines, 1999.

[22] TÜBİTAK MAM, "GAP Bölgesinde Sulamadan Dönen Suların Kontrolü ve Yeniden Kullanımı için İyileştirilmesinin Araştırılması Projesi”. Ankara, Ormam ve Su İşleri Bakanlığı, 2016.

[23] SALGOT, M. "Water reclamation, recycling and reuse: implementation issues", Desalination, 218, 190197, 2008.

[24] https://www.cdc.gov/healthywater/other/agricultural/index.html

[25] YURTSEVEN,E., ÇAKMAK, B., KESMEZ, D., POLAT, E., "Tarımsal Atıksuların Sulamada Yeniden Kullanılması”, Türkiye Ziraat Mühendisliği VII. Teknik Kongresi, TMMOB Ziraat Mühendisleri Odası, 2010.

[26] SCHOLZ, M., "Recycling of Domestic Wastewater Treated by Vertical -Flow Wetlands for Irrigation", Wetlands for Water Pollution Control, 2016.

[27] NANSUBUGA, I.G. "Optimal recovery of resources from wastewater treatment: aspects of the developing World" Ghent University. Faculty of Bioscience Engineering VII, 145 pp, 2015.

[28] PEDRERO, F., KALAVROUZítís, I., ALARCON, J.J., "Use of treated municipal wastewater in irrigated agriculture-Review of some practices in Spain and Greece", Agricultural Water Management, 97, 1233-1241, 2010.

[29] KAlaVRouZiotís, I.K., KANATAS, P.I., PAPADOPOUlOS, A.H., BLADEMOPOUlOU, S., KOUKOULAKIS, P.H., LEOTSINIDES, M.N. "Effects of municipal reclaimed wastewater on the macro and microelement status of soil and plants", Fresenius Environ. Bull. 14 (11), 1050-1057, 2005. 
[30] KALAVROUZIOTIS, I.K., ROBOLAS, P., KOUKOULAKIS, P.H., PAPADOPOULOS, A.H., "Effects of municipal reclaimed wastewater on the macro and microelements status of soil and of Brassica oleracea var. italica, and Brassica oleracea var. gemmifera. Int.", J. Agric. Water Manage. 95 (4), 419-426. 2008.

[31] DESBONNET, A., COSTA-PIERCE, B., "Aquaculture in future urban ecosystems", Urban aquaculture, Cromwell Press, UK. 2005.

[32] PIADEH, F., MOGHADDAM, M.R.A., MARDAN, S., "Present situation of wastewater treatment in the Iranian industrialestates: Recycle and reuse as a solution for achieving goals ofeco-industrial parks", Resources Conservation and Recycling, 92, 172-178, 2014.

[33] TANIK, A., ÖZTÜRK, İ., CÜCELOĞLU, G., "Arıtılmış Atıksuların Yeniden Kullanımı ve Yağmur Suyu Hasadı Sistemleri”, Türkiye Belediyeler Birliği, Ankara, 2015.

[34] ANGELAKIS, A. N., MARECOS DO MONTE, M. H., BONTOUX, L., ASANO, T., "The status of wastewater reuse practice in the Mediterranean Basin". Water Resources, 33, 2201-2217, 1999.

[35] USEPA. U.S. Environmental Protection Agency Guidelines for Water Reuse, 2004.

[36] QADIR, M., WICHELNS, D.,RASCHID-SALLY L., MCCORNICK, P.G., DRECHSEL, P., BAHRI, A., MINHAS, P.S., "The challenges of wastewater irrigation in developing countries", Agricultural Water Management, 97, 561-568, 2010.

[37] Cho, C.Y., Bureau, D.P. "Reduction of Waste Output from Salmonid Aquaculture through Feeds and Feeding", The Progressive Fish-Culturist, 59:155-160. 1997.

[38] LİANG J. "Refined structure of the FKBP12-rapamycin-FRB ternary complex at 2.2 A resolution", Acta Crystallogr D Biol Crystallogr, 55,4, 736-44, 1999.

[39] ZHOU A, "Proteolytic processing in the secretory pathway", J Biol Chem, 274,30, 20745-20748, 1999.

[40] PHONG LAN, N.T., DALSGAARD, A., CAM, P. D., MARA, D., "Microbiological quality of fish grown in wastewater-fed and non-wastewater-fed fishponds in Hanoi, Vietnam: influence of hygiene practices in local retail markets" Journal of Water and Health, 5 (2) 209-218, 2007.

[41] FELDLITE, M., JUANICÓ, M., KARPLUS, I., MILSTEIN, A., "Towards a safe standard for heavy metals in reclaimed water used for fish aquaculture" Aquaculture , 284, 115-126, 2008.

[42] ADHIKARİ, S., GHOSH, L., RAİ, S.P., AYYAPPAN, S., "Metal concentrations in water, sediment, and fish from sewage-fed aquaculture ponds of Kolkata, India", Environ Monit Assess. 159, 1-4, 217-230, 2009.

[43] RİJN, J. V., "Waste treatment in recirculating aquaculture systems", Aquacultural Engineering, 53, 49-56, 2013.

[44] DAVIDSON, J., GOOD, C., WELSH, C., BRAZIL, B., SNEKVIK, K., SUMMERFELT, S. T., "Heavy metal and waste metabolite accumulation and their affect on rainbow trout performance in a replicated water reuse system operated at low or high system flushing rates", Aquacult. Eng., 41:136-145, 2009.

[45] AZANU, D., JØRGENSEN, S.E., DARKO, G., STYRISHAVE, B., "Simple metal model for predicting uptake and chemical processes in sewage-fed aquaculture ecosystem", Ecological Modelling, 319, 130-136, 2016.

[46] PAL, D., MAITI, S. K., "Evaluation of Potential Human Health Risks from Toxic Metals via Consumption of Cultured Fish Species Labeo rohita: A Case Study from an Urban Aquaculture Pond", Expo Health, DOI 10.1007/s12403-017-0264-8., 2017.

[47] EDWARDS, P., "Wastewater-Fed Aquaculture Systems: Status and Prospects", NAGA, 19 (1), 33-35, 1996. The ICLARM, Quarterly. http://www.worldfishcenter.org/content/wastewater-fed-aquaculturesystems-status-and-prospects (accessed 19 August, 2016).

[48] GISECKE, U., HEILAND, S., Millíion, A., JUNGE, R. Urban Aquaculture, Deutsche National Bibliothek, Berlin, 2014.

[49] PREIN, M., "Wastewater-Fed Fish Culture in Germany, Wastewater-fed Aquaculture", Proceedings of the International Seminar on Wastewater Reclamation and Reuse for Aquaculture, Calcutta, India., 6-9 December 1988 (ed. Edwards, P and Pullin, R. S. V.) pp. 13-47, 1990.

[50] EDWARDS, P., "Public Health issues of waste water-fed aquaculture", Urban Agriculture Magazine, 3: 20$22,2001$.

[51] JANA, B.B., JANA, S., "The Potential and Sustainability of Aquaculture in India", Journal of Applied Aquaculture, 13, 3-4, 283-316, 2003.

[52] https://www.dunya.com/ekonomi/icdas-ilk-balik-hasadini-aldi-haberi-82068, Milliyet Gazetesi, 2011.

[53] http://www.konyaseker.com.tr/tr/icerik/detay/2077/balik-uretim-tesisi, Konya Şeker (2016).

[54] BLUMENTHAL, U.J., PEASEY, A., RUIZ-PALACIOS, G., MARA, D.D., "Guidelines for wastewater reuse in agriculture and aquaculture: recommended revisions based on new research evidence", The WELL Journal, 68-1, 2000. 
[55] USEPA. "Guidelines for Water Reuse”, EPA/625/R-92/004 September 1992, Washington. 262 pp. 1992.

[56] BASILLA, A., CASSANO, A., RASTOGİ, N.K., "Membrane technologies for water treatment and reuse in the food and beverage industries, Advances in Membrane Technologies for Water Treatment", Woodhead Publishing Series in Energy, 2015.

[57] SALLANKO, J., HAANPAA, K.M., "Practical Melting Forecasting of Artificial Snow Made from Treated Wastewater", Journal of Cold Regions Engineering, 24, 3, 87-95, 2010.

[58] ORTUNO, A., HERNANDEZ, M., CIVERA, S., "Golf course irrigation and self-sufficiency water in Southern Spain", Land Use Policy, 44, 10-18, 2015.

[59] CANDELA, L., FABREGAT, S., JOSA, A., JOSEP, S., VIGUUES, N., MAS, J., “Assessment of soil and groundwater impacts by treated urban wastewater reuse. A case study: Application in a golf course (Girona, Spain)", Science of the Total Environment, 374, 26-35, 2007.

[60] ORON, G., ADEL, M., AGMON, V., FRIEDLER, E., HALPERIN, R., LESHEM, E., WEINBERG, D., "Greywater use in Israel and worldwide: Standards and prospects", Water research, 58: 92-101, 2014.

[61] SANTOS, C., TAVEIRA-PINTTO, F., CHENG, C.Y., LEITE, D., "Development of an experimental system for greywater reuse", Desalination, 285, 301-305, 2012.

[62] PINTO, U., MAHESHWARI, B.L., GREWAL, H.S., "Effects of greywater irrigation on plant growth, water use and soil properties", Resources Conservation and Recycling, 54, 429-435, 2010.

[63] ÜSTÜN, G.E., TIRPANCI, A., "Gri Suyun Arıtımı ve Yeniden Kullanımı", Uludağ Üniversitesi Mühendislik Fakültesi Dergisi, 20,2, 119-139, 2015.

[64] GODFREY, S. SINGH, S., LABHASETWAR, P., DWIVEdi, H. B., PARIHAR, G., WATE, S. R., "Health-based targets for greywater reuse in residential schools in Madhya Pradesh, India", Water and Environment Journal, 24, 3, 215-222, 2010.

[65] NOLDE, E., "Greywater reuse systems for toilet fushing in multi-storey buildings - over ten years experience in Berlin", Urban Water, 1, 275-284, 1999.

[66] ANDERSON, J., BAGGETT, S., JEFFREY, P., MCPHERSON, L., MARKS, J., ROSENBLUM, E., "Public Acceptance of Water Reuse, In: Water Reuse: An International Survey of Current Practice, Issues and Needs", B. Jimenez and T. Asano (eds), 1st edn, IWA Publishing, London, UK, 2008.

[67] BÜYÜKKAMACI, N., ALKAN, H.S., "Public acceptance potential for reuse applications in Turkey", Resources Conservation and Recycling, 80, 32- 35, 2013.

[68] http://www.wwf.org.tr/ne_yapiyoruz/ayak_izinin_azaltilmasi/su/turkiyesuzenginibirulkemi/ Dünya Doğayı Koruma Vakfi (2017). 